Supplementary Information for:

\title{
Elucidating the role of halides and iron during radiolysis driven oxidative etching of gold nanocrystals using liquid cell TEM and pulse radiolysis
}

Michelle F. Crook, ${ }^{\dagger}$ Christian Laube, ${ }^{+`}$ Ivan A. Moreno-Hernandez, ${ }^{\dagger}$ Axel Kahnt, ${ }^{\ddagger}$ Stefan Zahn, ${ }^{\ddagger}$ Justin C. Ondry, ${ }^{+\| \#}$ Aijia Liu, ${ }^{+}$A. Paul Alivisatos. ${ }^{*}+, \Phi, \Phi, \|$

+Department of Chemistry and $\mathbf{g D e p a r t m e n t}$ of Materials Science and Engineering, University of California-Berkeley, Berkeley, California 94720, United States

\$Materials Sciences Division, Lawrence Berkeley National Laboratory, Berkeley, California 94720, United States

₹ Leibniz Institute of Surface Engineering (IOM), Permoserstr. 15, D-04318 Leipzig, Germany

\|Kavli Energy NanoScience Institute, University of California-Berkeley and Lawrence Berkeley National Laboratory, Berkeley, California 94720, United States

\section{Circularity Calculation}

Circularity is defined in this work according to Equation S1.

$$
C=\frac{4 \pi A}{P^{2}}(\mathrm{Eq} . \mathrm{S} 1)
$$

Where $\mathrm{A}$ is the projected area of the nanocrystal and $\mathrm{P}$ is the perimeter of the NC. If the shape measured is a perfect circle, then the circularity is $C=1$, while any deviations from a perfect circle give $C<1$. It is important to note that circularity is very sensitive to the perimeter of the shape being measured. This means that if there are errors during segmentation (binarization, how the outline of the AuNC is determined), the calculated circularity can be misleading. Figure $\mathbf{S 2}$ shows a representative outlining for the etching trajectory snapshots of the studied environments. The segmentation code used for this analysis produces a smooth perimeter very near the actual edge of the nanocrystal. Additionally, only the largest boundary in each frame is selected to calculate the circularity. This removes any interference from high contrast precipitates that may form throughout the etching trajectory, as can be seen in the final frames of Figure S2. These precipitates in solution have been suggested to be iron species related to the preloaded $\mathrm{FeCl}_{3}$, yet more studies are needed to determine the exact identity of these species and how they relate to the AuNC etching mechanism. 


\section{Quantification of AuNC Etch Rate}

For the LCTEM etching studies presented in this manuscript, the projected area $v s$. time was used to quantify the etch rate of the nanocrystals. The metric was chosen as it can be consistent across all experimental conditions, including the nanocrystals in trace bromide and iodide environments that change shape throughout their etching trajectory. Gold nanocrystal etching with $\mathrm{FeCl}_{3}$ has been shown to be linear after an initial induction period when plotted as surface area $v s$. time. ${ }^{1}$ In this study, they rationalize the linear surface area $v s$. time curve by suggesting a mechanism which is dependent on both the gold surface and the oxidant. For a sphere, surface area and projected area only differ by a factor of 4 , indicating that for the nanocrystals in chloride environment the etch rate is linear with surface area, as seen in previous studies. While only the nanocrystals in chloride remain spherical throughout the etching trajectory, meaning only their projected areas are proportional to surface area, we expect the mechanisms to be similar under all halide environments, as the halides control the rate of removal of the oxidized gold atoms, not whether or not they are removed.

\section{Additional Pulse Radiolysis Experiments}

In addition to the reaction of $\mathrm{Fe}(\mathrm{III})$ with $\mathrm{Cl}_{2}{ }^{\bullet-}$, the reaction of $\mathrm{Fe}$ (III) with $\mathrm{SO}_{4}{ }^{\bullet-}$ - another strongly oxidizing intermediate with an oxidation potential of $+2.4 \mathrm{~V}_{\mathrm{vs}}$. $\mathrm{NHE}^{2}-$ was probed. The $\mathrm{SO}_{4}{ }^{\bullet-}$ radical is formed in a nitrogen saturated aqueous solution containing $\mathrm{K}_{2} \mathrm{~S}_{2} \mathrm{O}_{8}$ and 5 vol\% $t-\mathrm{BuOH}$. The radiolysis of such solutions initially forms of the products of the water radiolysis $\left({ }^{\bullet} \mathrm{OH},{ }^{\bullet} \mathrm{H}\right.$ and $\mathrm{e}_{\mathrm{aq}}{ }^{-}$). The $t$ - $\mathrm{BuOH}$ efficiently scavenges the ${ }^{\circ} \mathrm{OH}$ and ${ }^{\bullet} \mathrm{H}$ radicals. The solvated electron reacts with $\mathrm{S}_{2} \mathrm{O}_{8}{ }^{2-}$ to form $\mathrm{SO}_{4}{ }^{2-}$ and $\mathrm{SO}_{4}{ }^{\bullet-}$. The latter is discernable by its characteristic transient absorption spectrum with a maximum around $450 \mathrm{~nm}$ (see Figure S6 A). ${ }^{3}$ When $\mathrm{Fe}(\mathrm{IIII}$ ) is added to this the solution, initially the transient absorption spectrum of $\mathrm{SO}_{4}{ }^{--}$is observed, but with increasing delay time a negative transient absorption develops in the spectral region below $350 \mathrm{~nm}$ (see Figure S6 C), where $\mathrm{Fe}(\mathrm{III})$ shows abortions, similar to the reaction of $\mathrm{Fe}(\mathrm{III})$ with $\mathrm{Cl}_{2}{ }^{\bullet}$. This is indicative of a reaction of $\mathrm{Fe}(\mathrm{III})$ with $\mathrm{SO}_{4}{ }^{\bullet-}$ (compare Figures $\mathbf{S 6} \mathbf{B}$ and S6 D).

\section{Additional information on computational studies}

Initially, we have investigated the stability of diverse oxidized Fe-complexes. We have included complexes with six ligands possessing one or two chloride anions as ligands. The remaining ligands were water or OH-groups. For each isomer, we have included seven possible electronic structures in our study. Four of the seven electronic structures started with default values for multiplicities of 1, 3, 5, 7 resulting mainly in electronic structures with increased $\alpha$ spin density on all atoms. The electronic structure of multiplicities 3,5 and 7 served subsequently as initial input for antiferromagnetic structures with multiplicity of 1,3 and 5 , respectively. In these cases, the 
spin density on the iron atom was flipped in the initial guess of the wave function. Figure S9, S10, S11 and S12 show all obtained stable electronic structures for each isomer where the energy of the most stable electronic structure of each isomer was set to $0 \mathrm{~kJ} / \mathrm{mol}$. A comparison of the stability of the isomers to each other is provided in Figure S13.

Finally, we compared the complexes to each other, see Figure S14. The $p K_{a}$-value of the Fecomplexes were determined by following equation:

$$
p K_{a}(F e)=p K_{a}\left(F e_{r e f}\right)+\frac{G\left(F e^{-}\right)+G\left(F e H_{r e f}\right)-G(F e H)-G\left(F e_{r e f}^{-}\right)}{2.303 \cdot R \cdot T}
$$

where $p K_{a}\left(F e_{r e f}\right)$ is the experimental $p K_{a}$-value of $\mathrm{Fe}(\mathrm{III})\left(\mathrm{H}_{2} \mathrm{O}\right)_{6}{ }^{3+}(2.22) . G(F e H)$ and $G\left(F e^{-}\right)$ are the calculated Gibbs free energy of the protonated and deprotonated Fe-complex, respectively. $G\left(\mathrm{FeH}_{\text {ref }}\right)$ and $G\left(\mathrm{Fe}_{\text {ref }}^{-}\right)$refers to the Gibbs free energy of $\mathrm{Fe}(\mathrm{III})\left(\mathrm{H}_{2} \mathrm{O}\right)_{6}{ }^{3+}$, protonated and deprotonated. We have chosen $\mathrm{Fe}(\mathrm{III})\left(\mathrm{H}_{2} \mathrm{O}\right)_{6}{ }^{3+}$ as reference due to the similarity to our investigated system which is essential to calculate accurate $p K_{a}$-values by isodesmic reactions. ${ }^{4}$ Furthermore, we have employed the SMD solvation model $^{5}$ for the calculation of $p K_{a}$-values and Gibbs free energies between different complexes shown in Figure S14 and S15. The SMD solvation model excels C-PCM in accuracy and provides $p K_{a}$-values in solution surpassing approaches based on thermodynamic cycles. ${ }^{6}$ These calculations showed that $m e r 1-\mathrm{FeCl}_{2}\left(\mathrm{H}_{2} \mathrm{O}\right)_{3} \mathrm{OH}^{+}$should be the most stable oxidized complex under the experimental conditions. A similar protocol was applied to the Fe-complex before the oxidation where solely high spin states were considered. Figure $\mathbf{S 1 5}$ shows the comparison of the most stable structures highlighting that trans- $\mathrm{FeCl}_{2} \mathrm{H}_{2} \mathrm{O}_{4}{ }^{+}$is most stable in solution. Finally, CASSCF calculations of the most stable complexes were carried out where the orbitals of the active space are shown in Figure S16

\section{Supporting Figures}




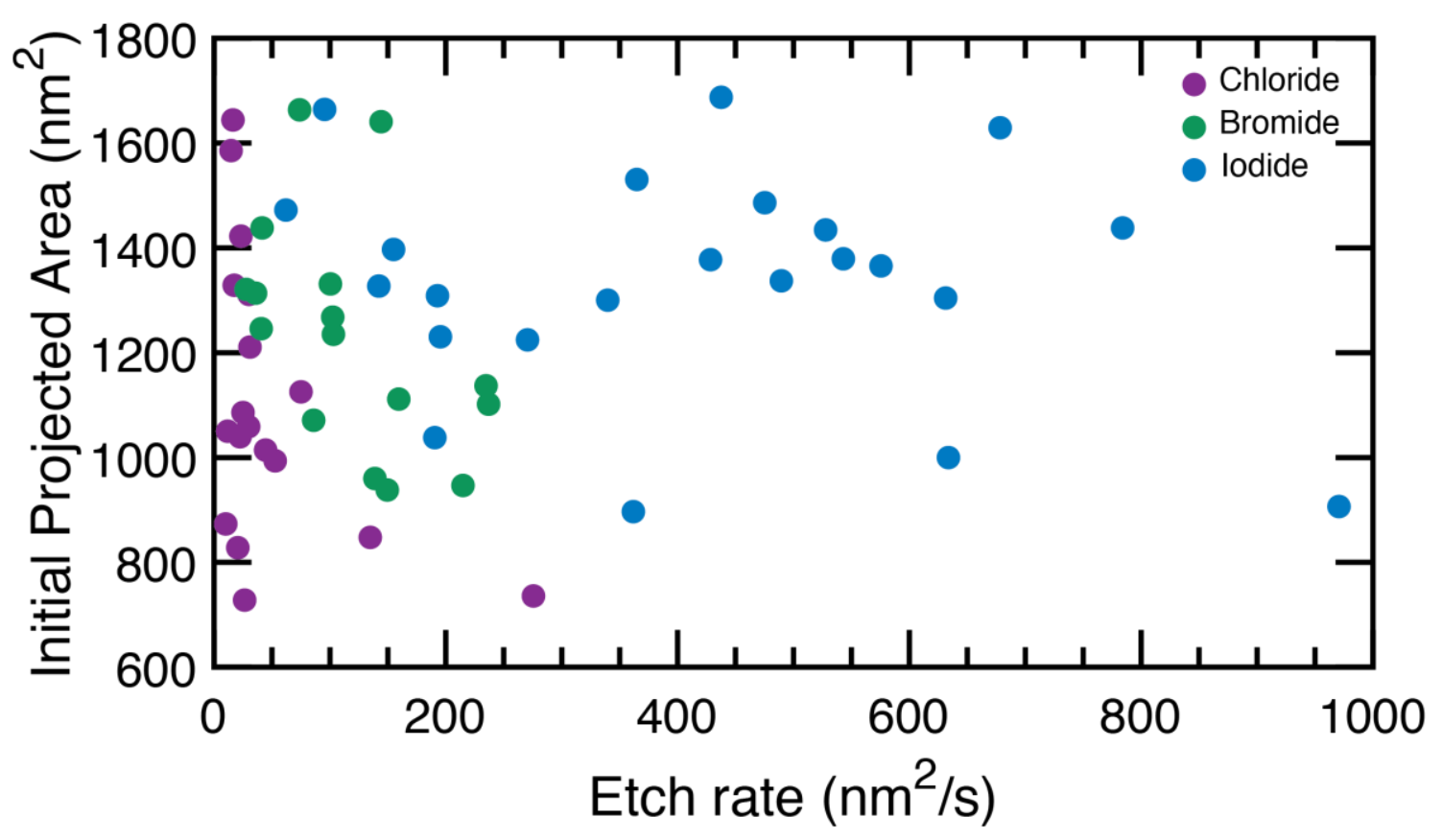

Figure S1. Comparison of initial projected area and etch rate for nanocrystals in solution with $190 \mathrm{mM} \mathrm{Cl}^{-}$and $40 \mathrm{mM} \mathrm{Fe}(\mathrm{III})$ (purple), $190 \mathrm{mM} \mathrm{Cl}^{-}, 0.38 \mathrm{mM} \mathrm{Br}{ }^{-}$and $40 \mathrm{mM} \mathrm{Fe}(\mathrm{III})$ (green) and $190 \mathrm{mM} \mathrm{Cl}^{-}, 0.38 \mathrm{mM} \mathrm{I}^{-}$and $40 \mathrm{mM} \mathrm{Fe}(\mathrm{III})$ (blue). There is not a strong dependence between initial size and etch rate in these experiments. The average initial size and standard deviation for the chloride, bromide, and iodide environments are $1104 \mathrm{~nm}^{2} \pm 269 \mathrm{~nm}^{2}, 1232 \mathrm{~nm}^{2} \pm 221 \mathrm{~nm}^{2}$, and $1336 \mathrm{~nm}^{2} \pm 216 \mathrm{~nm}^{2}$, respectively. 
No Fe(III)
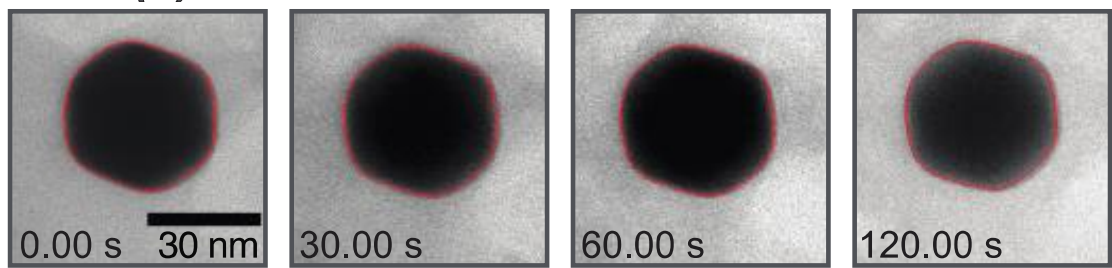

$\mathrm{Fe}(\mathrm{III})+\mathrm{Cl}^{-}$
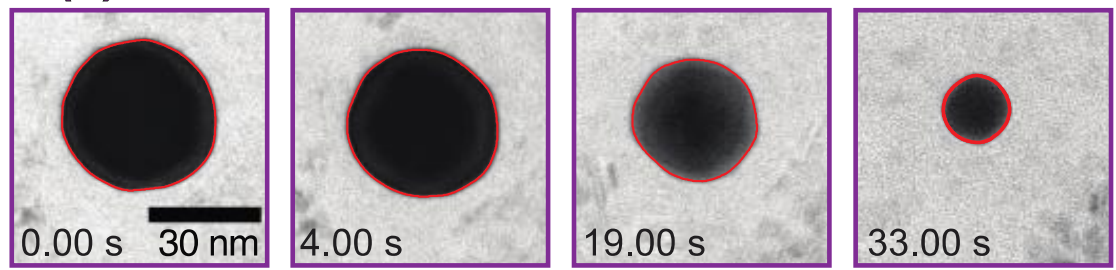

\section{$\mathrm{Fe}(\mathrm{IIII})+B \mathrm{r}^{-}$}
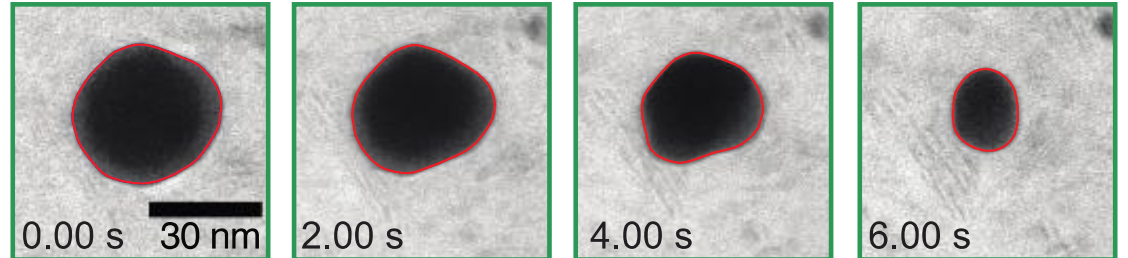

$\mathrm{Fe}(\mathrm{IIII})+I^{-}$
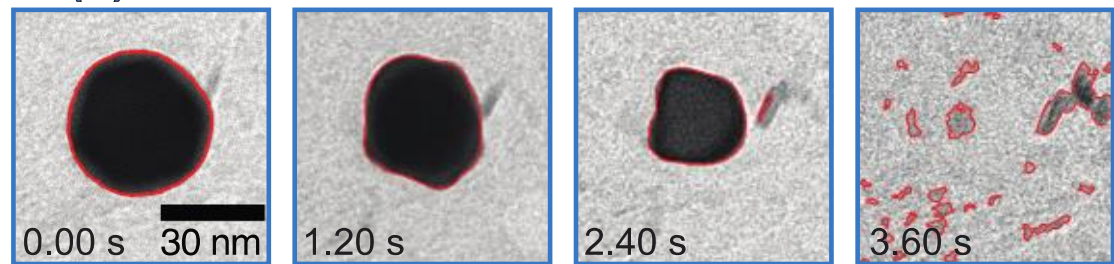

Figure S2. Segmentation used to calculate circularity of each nanocrystal. The perimeters are relatively smooth, decreasing error due to noise of the outline. However, as the nanocrystals near the very end of their etching trajectories, the contrast becomes very low, and the segmentation becomes less reliable. As the error in segmentation increases near the very end of the etching trajectories, the circularity increases, which is likely the cause of in the increase in circularity at the end of all the nanocrystal etching trajectories, and a circularity greater than 1 at the end of the etching trajectory for the nanocrystals in the chloride environment. 

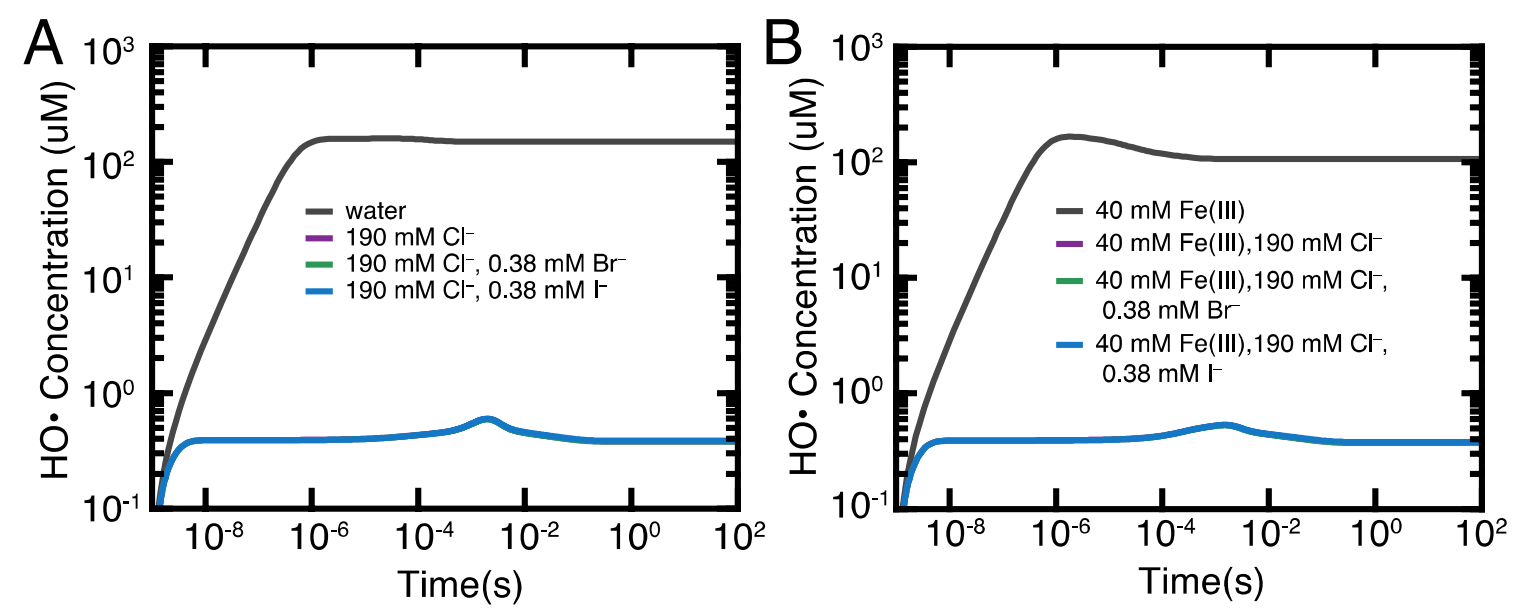

Figure S3. Simulated steady state concentration of $\cdot \mathrm{OH}$ radicals under various halide conditions. A) $\cdot \mathrm{OH}$ radical concentration in neat water (grey), and with $190 \mathrm{mM} \mathrm{Cl}^{-}$(purple), $190 \mathrm{mM} \mathrm{Cl}^{-}$\& $0.38 \mathrm{mM} \mathrm{Br}^{-}$(green), and $190 \mathrm{mM} \mathrm{Cl}^{-} \& 0.38 \mathrm{mM} \mathrm{I}^{-}$(blue). B) $\cdot \mathrm{OH}$ radical concentration under the four experimental concentrations tested. $40 \mathrm{mM} \mathrm{Fe}$ (III) (grey), $40 \mathrm{mM} \mathrm{Fe}$ (III) \& $190 \mathrm{mM} \mathrm{Cl}^{-}$ (purple), $40 \mathrm{mM} \mathrm{Fe}(\mathrm{III}), 190 \mathrm{mM} \mathrm{Cl}^{-} \& 0.38 \mathrm{mM} \mathrm{Br}^{-}$(green), and $40 \mathrm{mM} \mathrm{Fe}(\mathrm{III}), 190 \mathrm{mM} \mathrm{Cl}^{-}$\& $0.38 \mathrm{mM} \mathrm{I}^{-}$(blue). Chloride, bromide, and iodide solutions are overlapped in both A) and B).

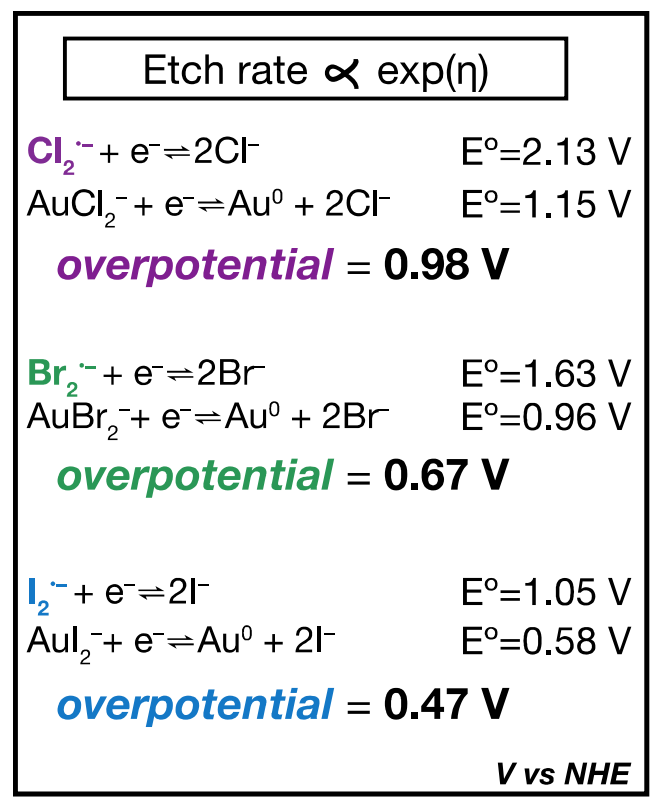

Figure S4. Overpotential $(\eta)$ when halides act as oxidant and complexation agent. The overpotential for etching decreases moving down group 17. If this were the predominating mechanism, a decrease in etch rate would be observed as the overpotential is proportional to the exponential of etch rate in a high driving force regime. 


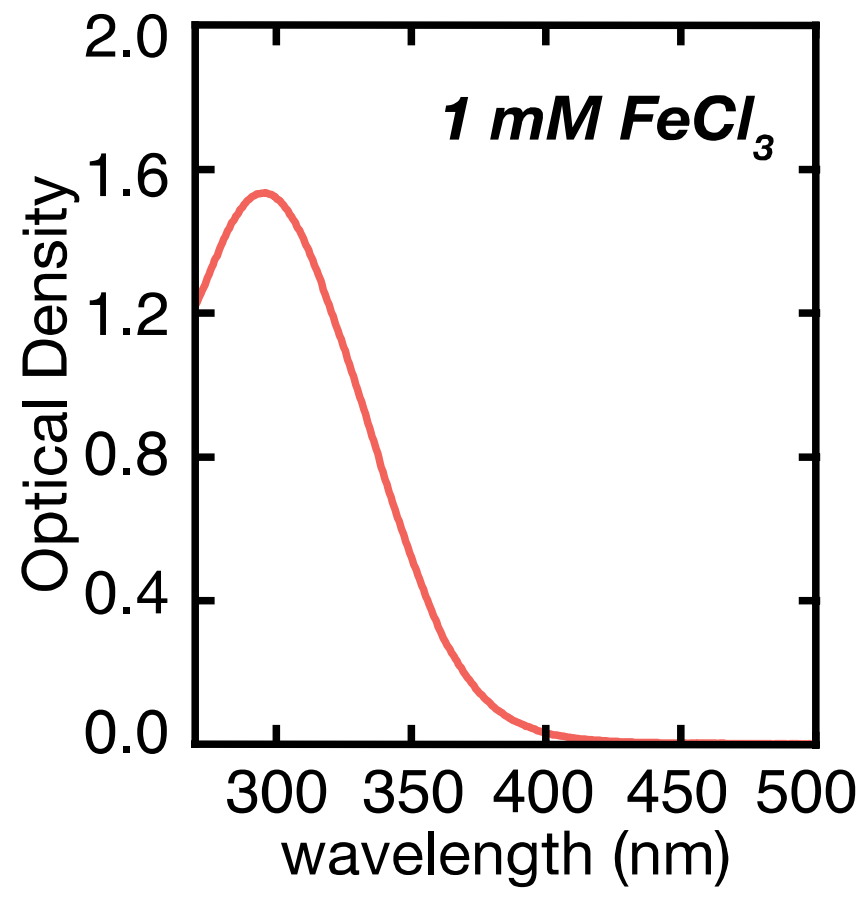

Figure S5. Optical density of the $1 \mathrm{mM} \mathrm{FeCl}_{3}$ in $0.2 \mathrm{M} \mathrm{HCl}$ solution used in the pulse radiolysis studies. Note the strong absorbance in the $290-360 \mathrm{~nm}$ wavelength range, where the ground state bleaching in the pulse radiolysis studies is observed. 

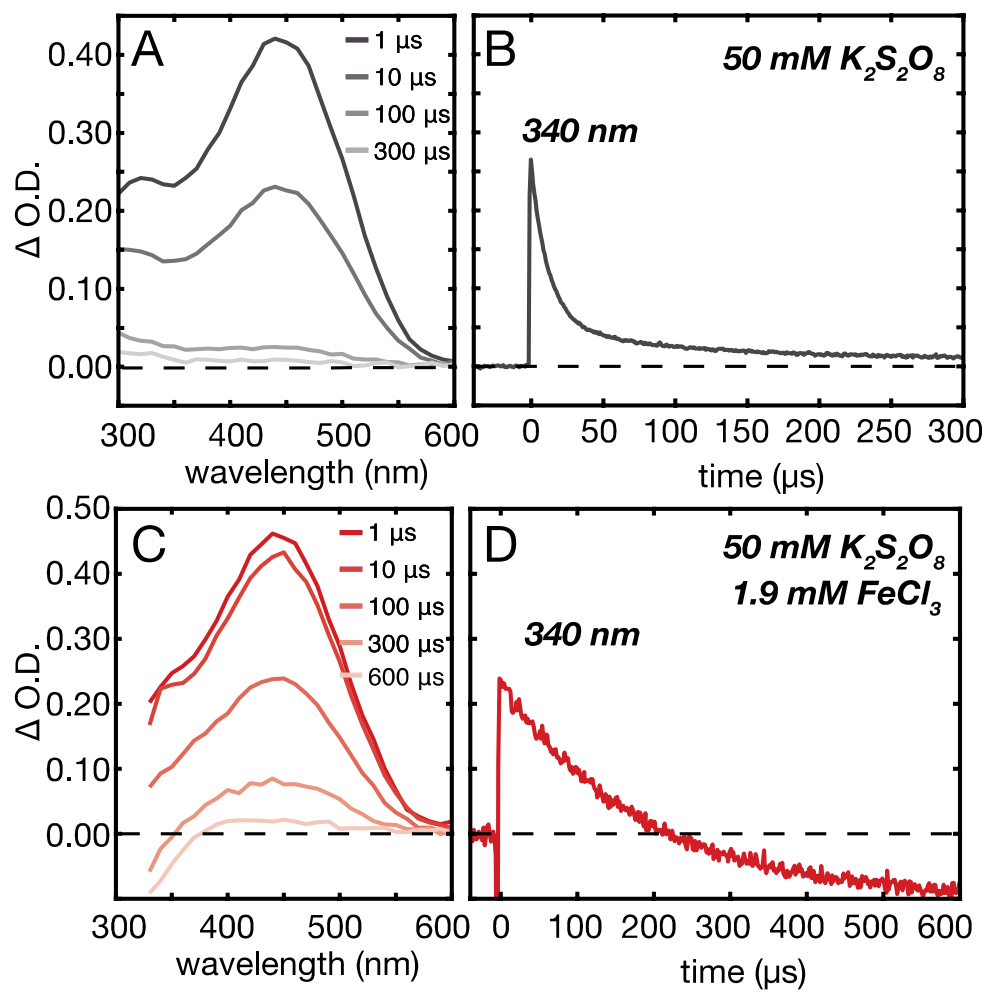

Figure S6. A) Pulse radiolysis measurement ( 85 Gy/pulse, 15ns FWHM) of an $\mathrm{N}_{2}$ saturated aqueous solution containing $50 \mathrm{mM}$ potassium persulfate and $5 \mathrm{Vol} \% \mathrm{t}-\mathrm{BuOH}$ B) Corresponding time absorption profile at $340 \mathrm{~nm}$. C) Pulse radiolysis measurement (85 Gy/pulse, $15 \mathrm{~ns}$ FWHM) of an $\mathrm{N}_{2}$ saturated aqueous solution containing $50 \mathrm{mM}$ potassium persulfate, $1.9 \mathrm{mM} \mathrm{Fe}\left(\mathrm{NO}_{3}\right)_{3}$ and $5 \mathrm{Vol} \% \mathrm{t}$-BuOH. D) Corresponding time absorption profile at $340 \mathrm{~nm}$ 


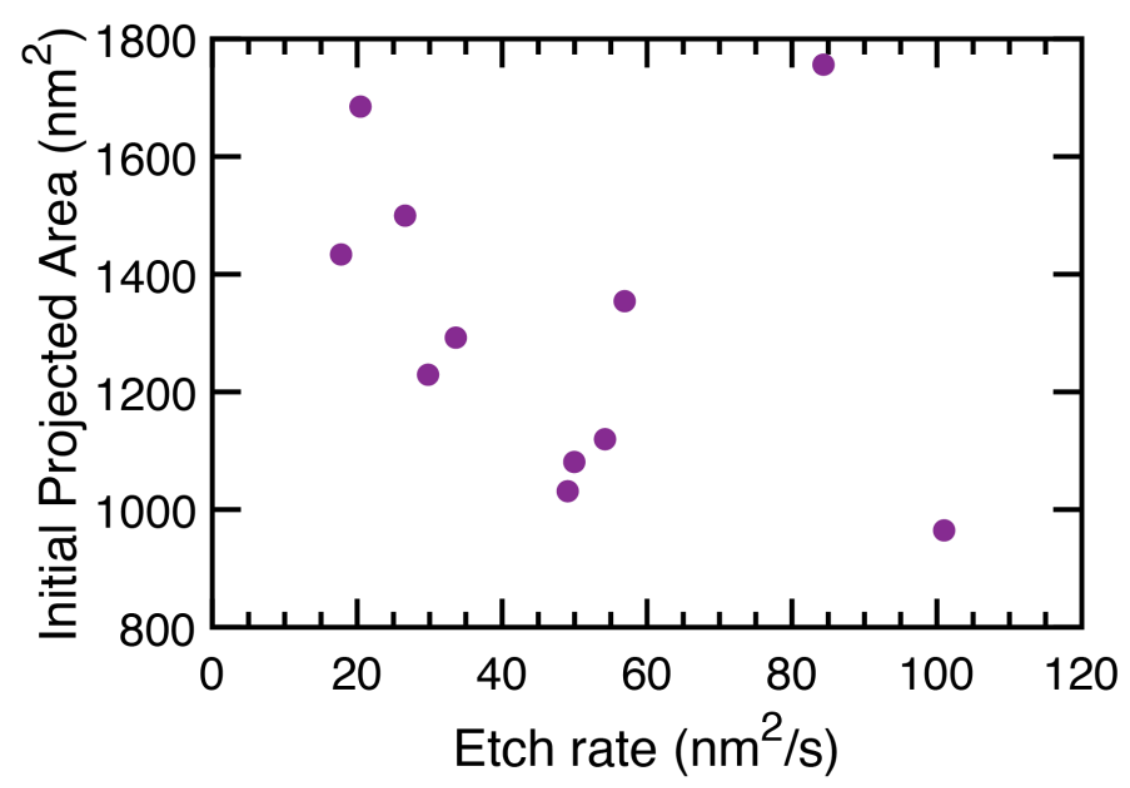

Figure S7. Comparison of initial projected area and initial etch rate at $800 \mathrm{e}^{-} / \AA^{2} \mathrm{~s}$ for nanocrystals in solution with $190 \mathrm{mM} \mathrm{Cl}^{-}$and $40 \mathrm{mM} \mathrm{Fe(III)} \mathrm{for} \mathrm{the} \mathrm{dose} \mathrm{decrease} \mathrm{experiments} \mathrm{in} \mathrm{Figure} 4$. There is not a strong correlation between initial size and etch rate. The average initial projected area for these nanocrystals is $1313 \mathrm{~nm}^{2} \pm 262 \mathrm{~nm}^{2}$
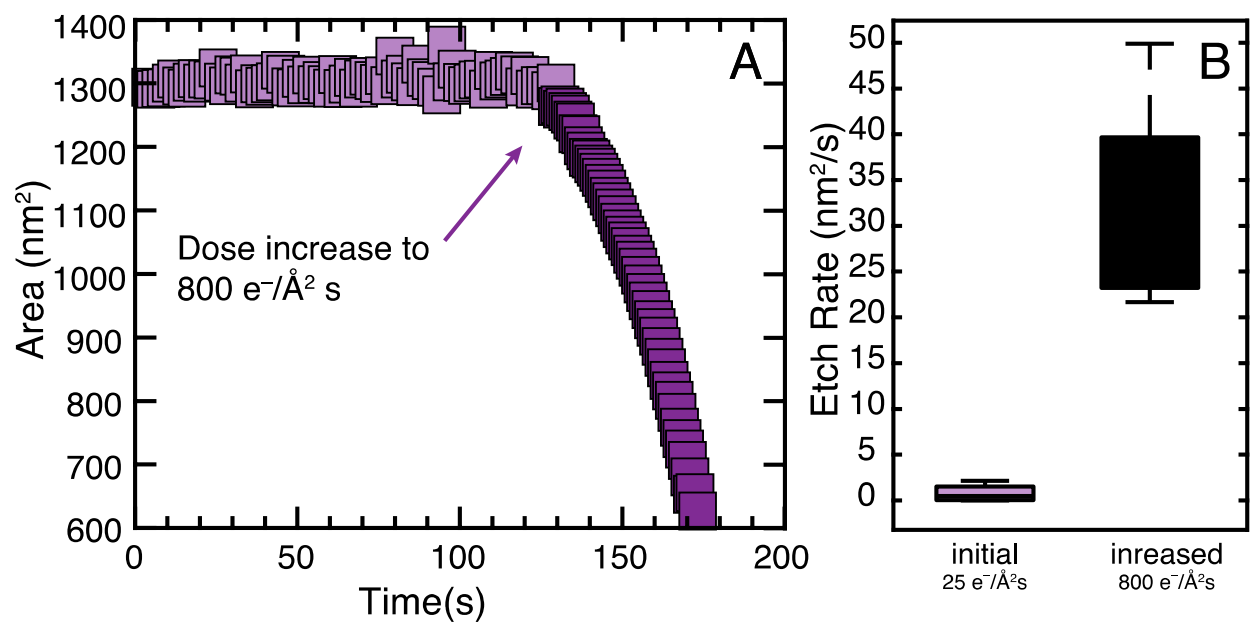

Figure S8. Increase of etch rate during controls shown in Figure 3B. During the control, the dose rate was held at $25 \mathrm{e}^{-} / \AA^{2} \mathrm{~s}$ for 1-2 minutes. To confirm that the nanocrystals used for the control experiments were in liquid, and lack of etching was not due to a dry pocket, the dose rate was increased to $800 \mathrm{e}^{-} / \AA^{2} \mathrm{~s}$ after 1-2 minutes. The onset of etching after the dose increase confirms that the nanocrystals were in solution. A) Etching trajectory of a gold nanocrystal initially irradiated at $25 \mathrm{e}^{-} / \AA^{2} \mathrm{~s}$. The dose rate was increased to $800 \mathrm{e}^{-/} \AA^{2} \mathrm{~s}$ after $130 \mathrm{~s}$ and the gold nanocrystal began to etch. B) Box and whisker plot summarizing the control etching trajectories under these conditions. The average etch rate of the AuNCs after increasing the dose rate significantly increases the etch rate. 

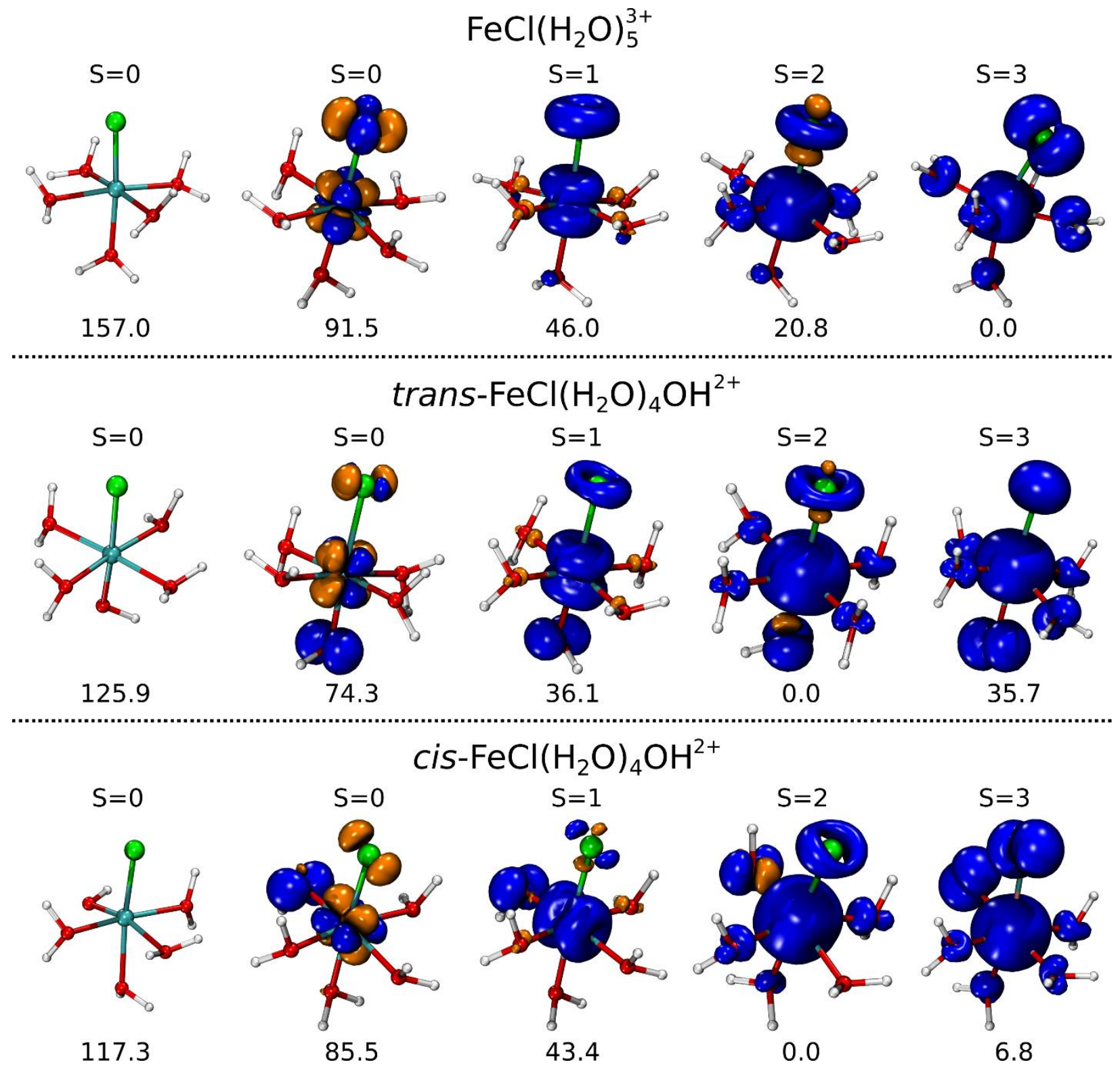

Figure S9. Spin density of each Fe-complex with one Cl-atom and up to one $\mathrm{OH}$ group as ligand. The blue isosurface highlights regions of increased $\alpha$ spin density while orange are regions of increased $\beta$ spin density. On top of each complex is shown the total spin $\mathrm{S}$ of the system while the Gibbs free energy is given below each complex. All energies are given in $\mathrm{kJ} / \mathrm{mol}$ and the most stable electronic structure of each isomer was set to $0 \mathrm{~kJ} / \mathrm{mol}$. 


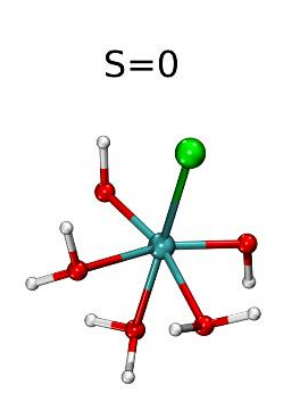

76.0

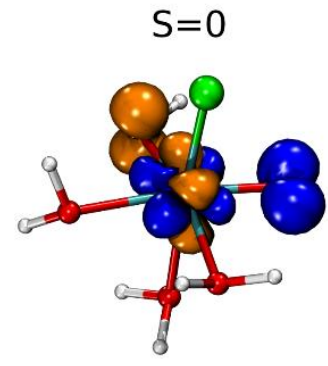

43.0

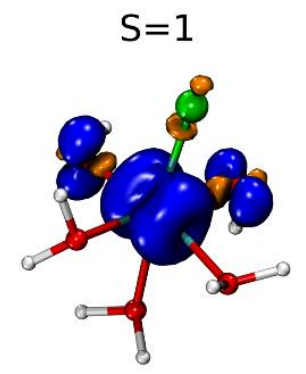

0.0

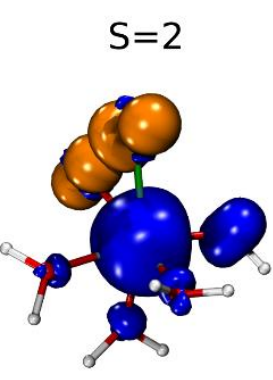

13.3

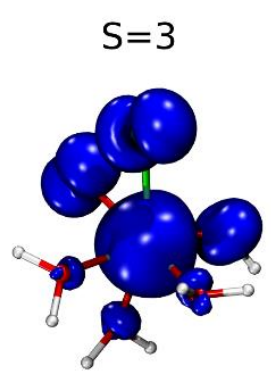

7.4

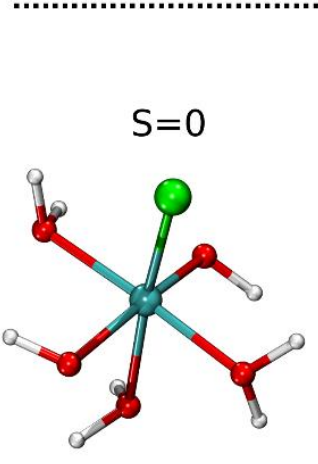

124.3

\section{merl- $\mathrm{FeCl}\left(\mathrm{H}_{2} \mathrm{O}\right)_{3}(\mathrm{OH})_{2}^{+}$}

93.3

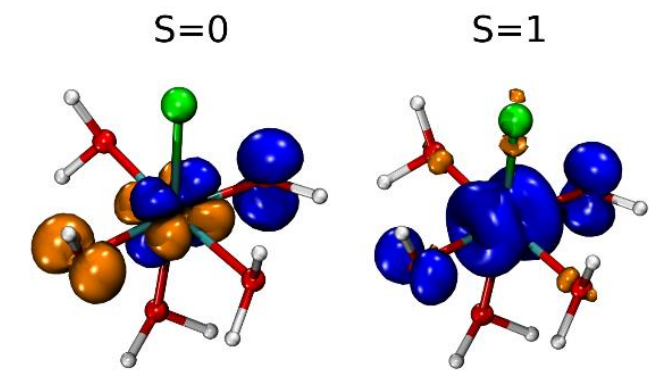

49.7

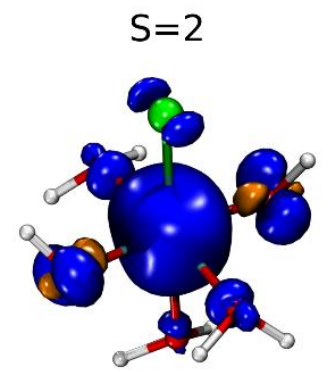

0.0

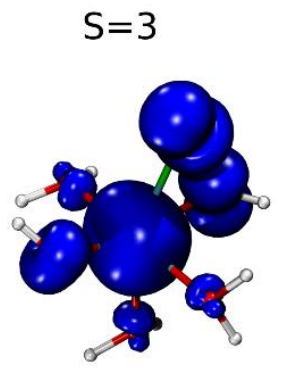

48.7

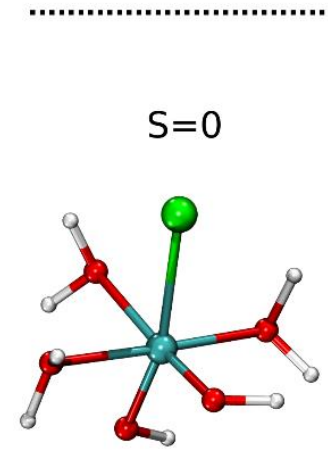

108.1

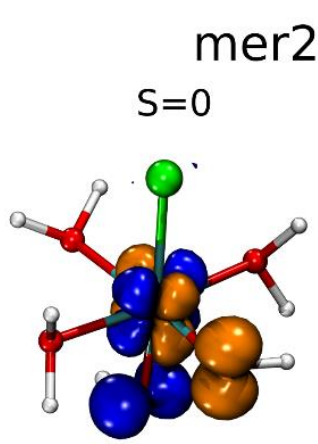

90.2

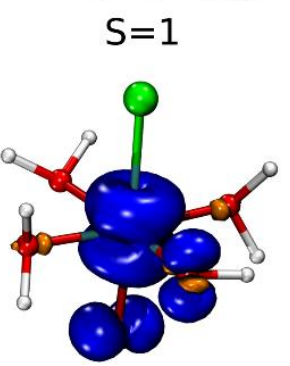

52.1

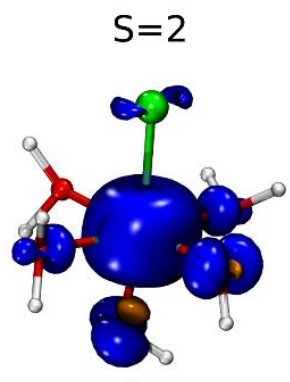

0.0

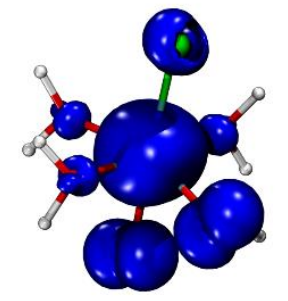

49.1

Figure S10. Spin density of each Fe-complex with one $\mathrm{Cl}$-atom and two $\mathrm{OH}$ groups as ligands. The blue isosurface highlights regions of increased $\alpha$ spin density while orange are regions of increased $\beta$ spin density. On top of each complex is shown the total spin $S$ of the system while the Gibbs free energy is given below each complex. All energies are given in $\mathrm{kJ} / \mathrm{mol}$ and the most stable electronic structure of each isomer was set to $0 \mathrm{~kJ} / \mathrm{mol}$. 


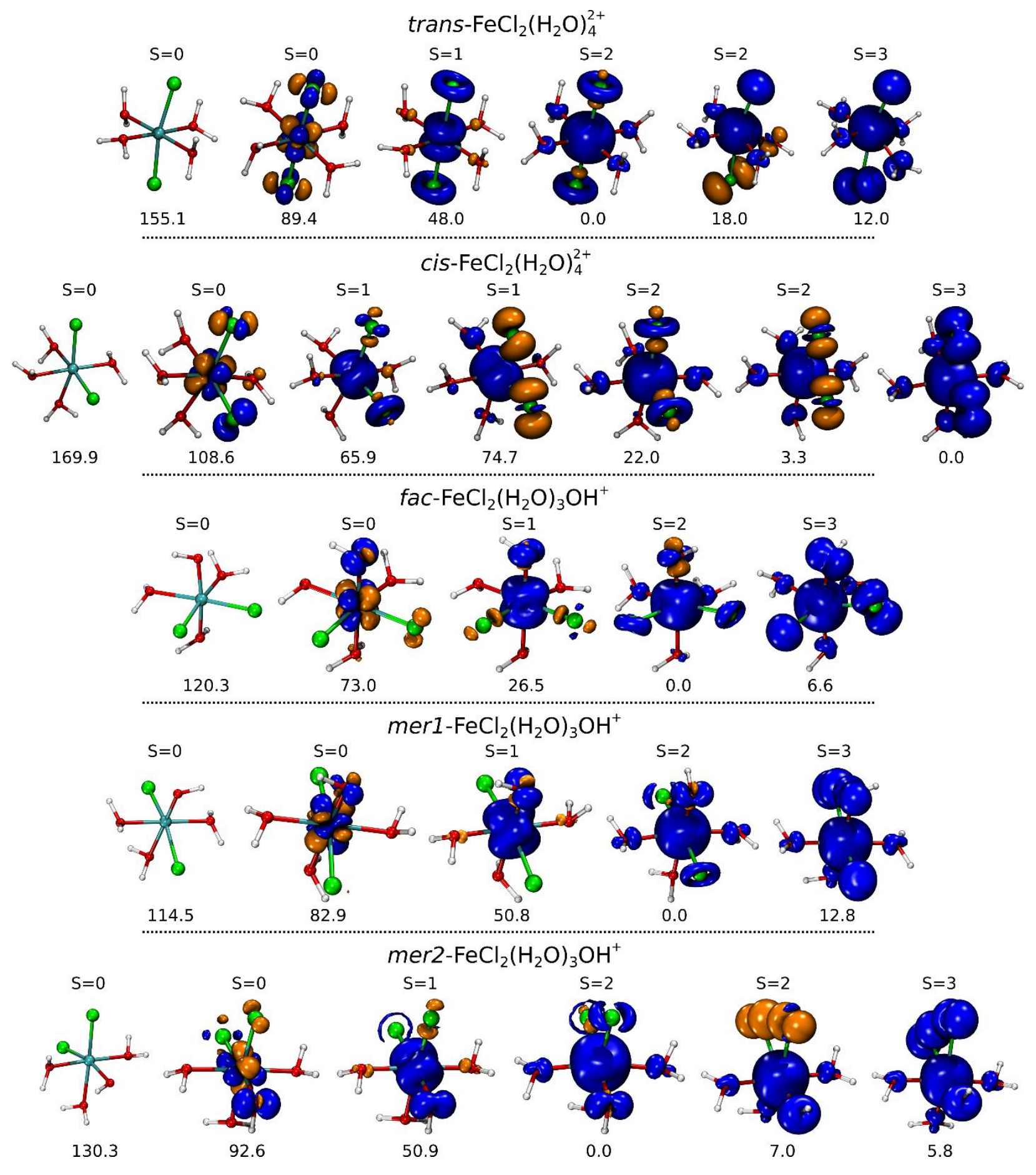

Figure S11. Spin density of each Fe-complex with two Cl-atoms and up to one OH group as ligand. Blue areas indicate regions of increased $\alpha$ spin density while orange highlights regions of increased $\beta$ spin density. On top of each complex is shown the total spin $\mathrm{S}$ of the system while the Gibbs free energy is given below each complex. All energies are given in $\mathrm{kJ} / \mathrm{mol}$ and the most stable electronic structure was set to $0 \mathrm{~kJ} / \mathrm{mol}$ for each isomer. 

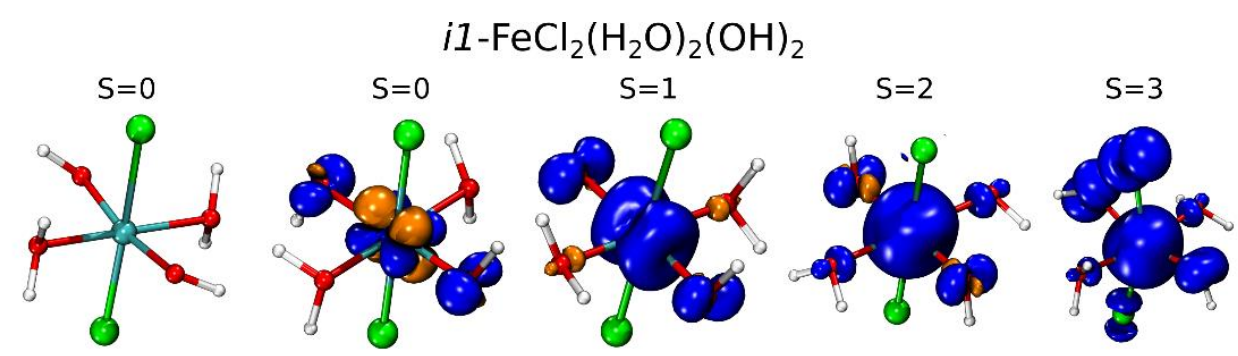

135.7

100.2

54.4

0.0

43.3

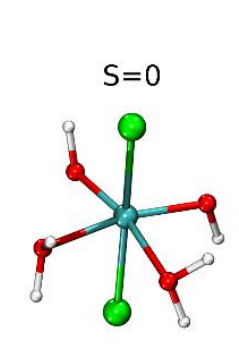

77.8

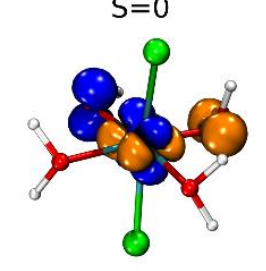

i2- $\mathrm{FeCl}_{2}\left(\mathrm{H}_{2} \mathrm{O}\right)_{2}(\mathrm{OH})_{2}$
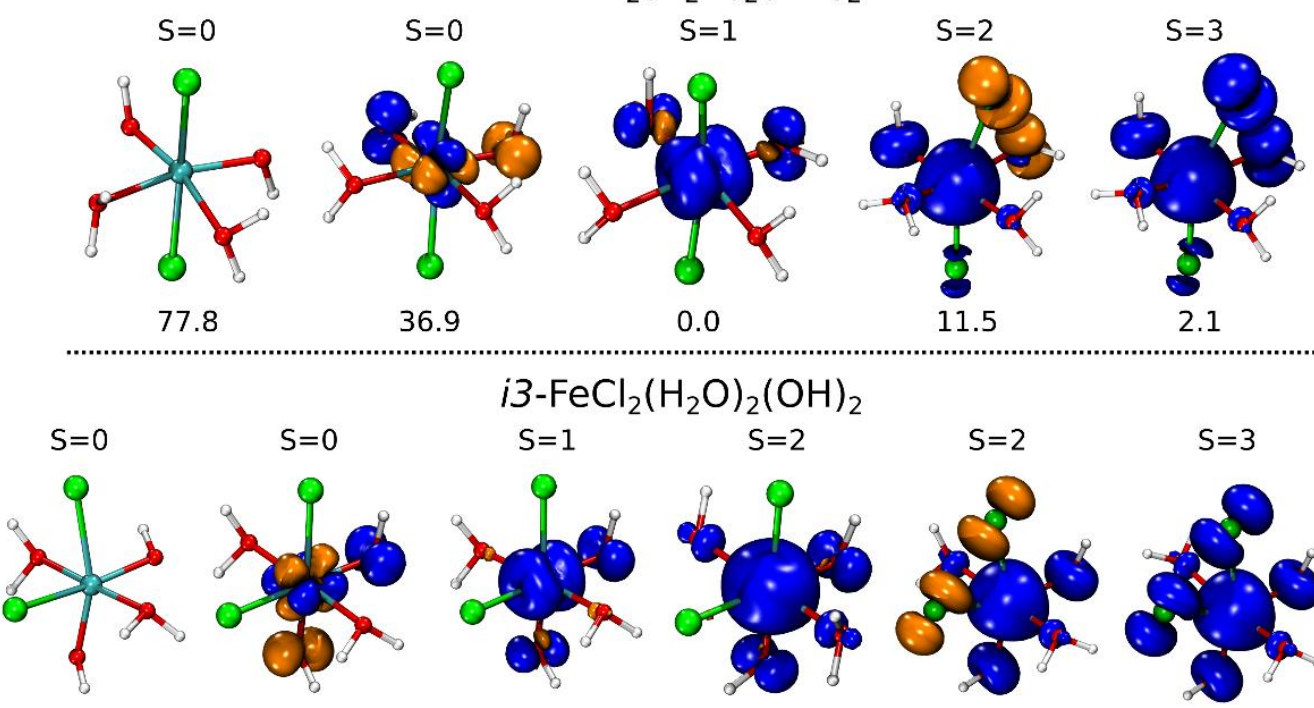

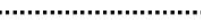

36.9

0.0

11.5

2.1

134.0

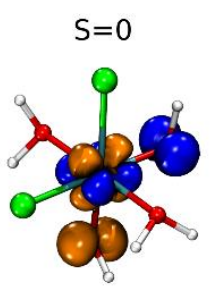

i3- $\mathrm{FeCl}_{2}\left(\mathrm{H}_{2} \mathrm{O}\right)_{2}(\mathrm{OH})_{2}$
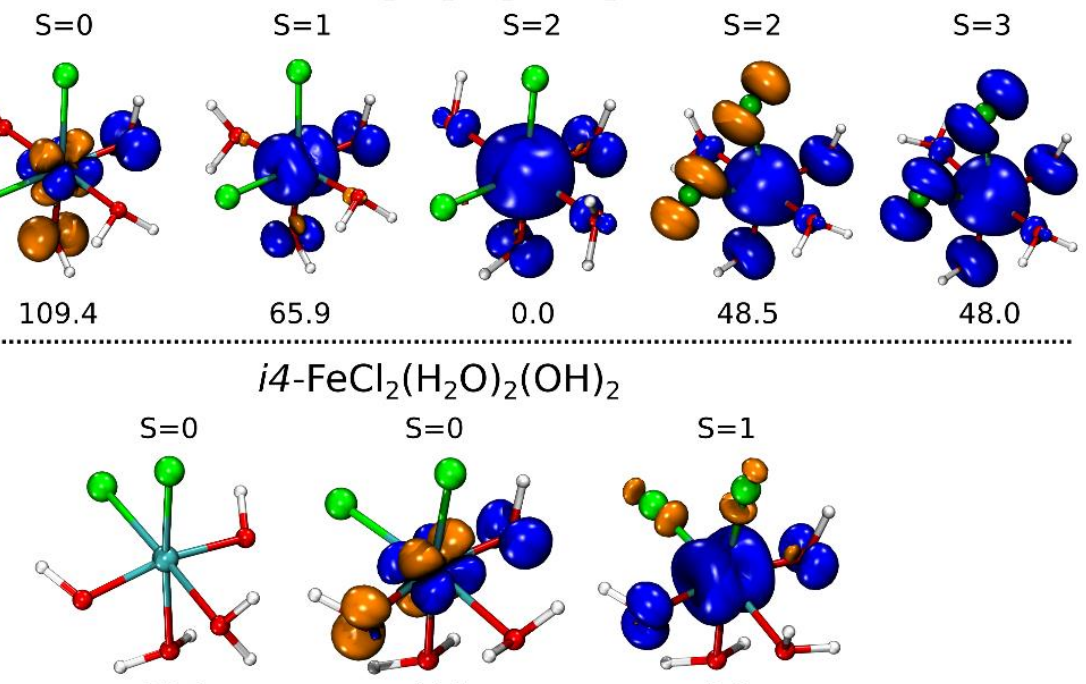

65.9

0.0

48.5

48.0

86.5

44- $\mathrm{FeCl}_{2}\left(\mathrm{H}_{2} \mathrm{O}\right)_{2}(\mathrm{OH})_{2}$

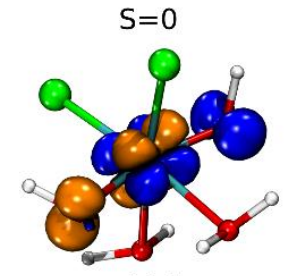

46.8

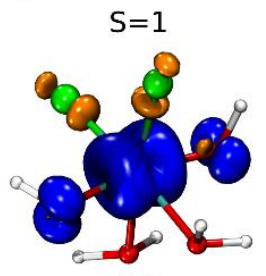

0.0

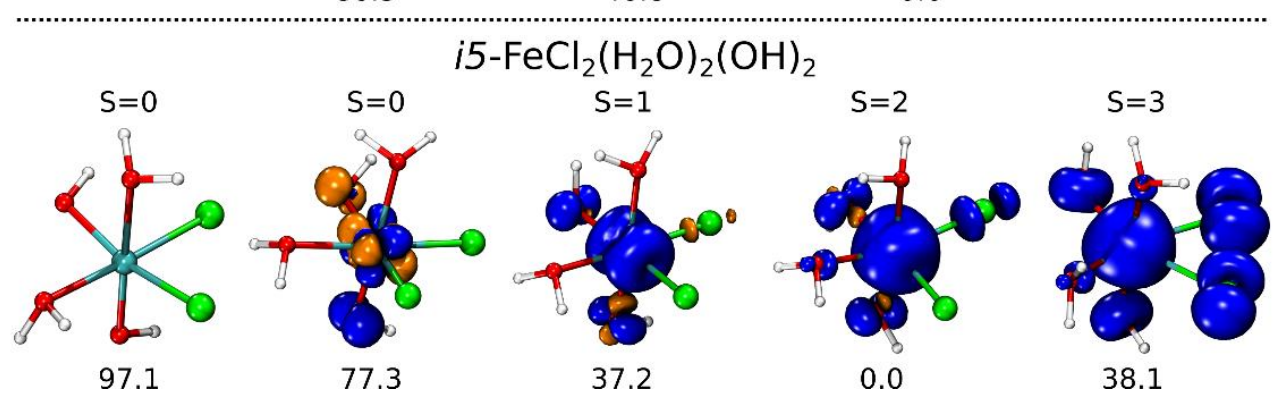

Figure S12. Spin density of each Fe-complex with two Cl-atoms and two OH-groups as ligand. Blue areas indicate regions of increased $\alpha$ spin density while orange highlights regions of increased $\beta$ spin density. On top of each complex is shown the total spin $S$ of the system while the Gibbs free energy is given below each complex. All energies are given in $\mathrm{kJ} / \mathrm{mol}$ and the most stable electronic structure was set to $0 \mathrm{~kJ} / \mathrm{mol}$ for each isomer. 


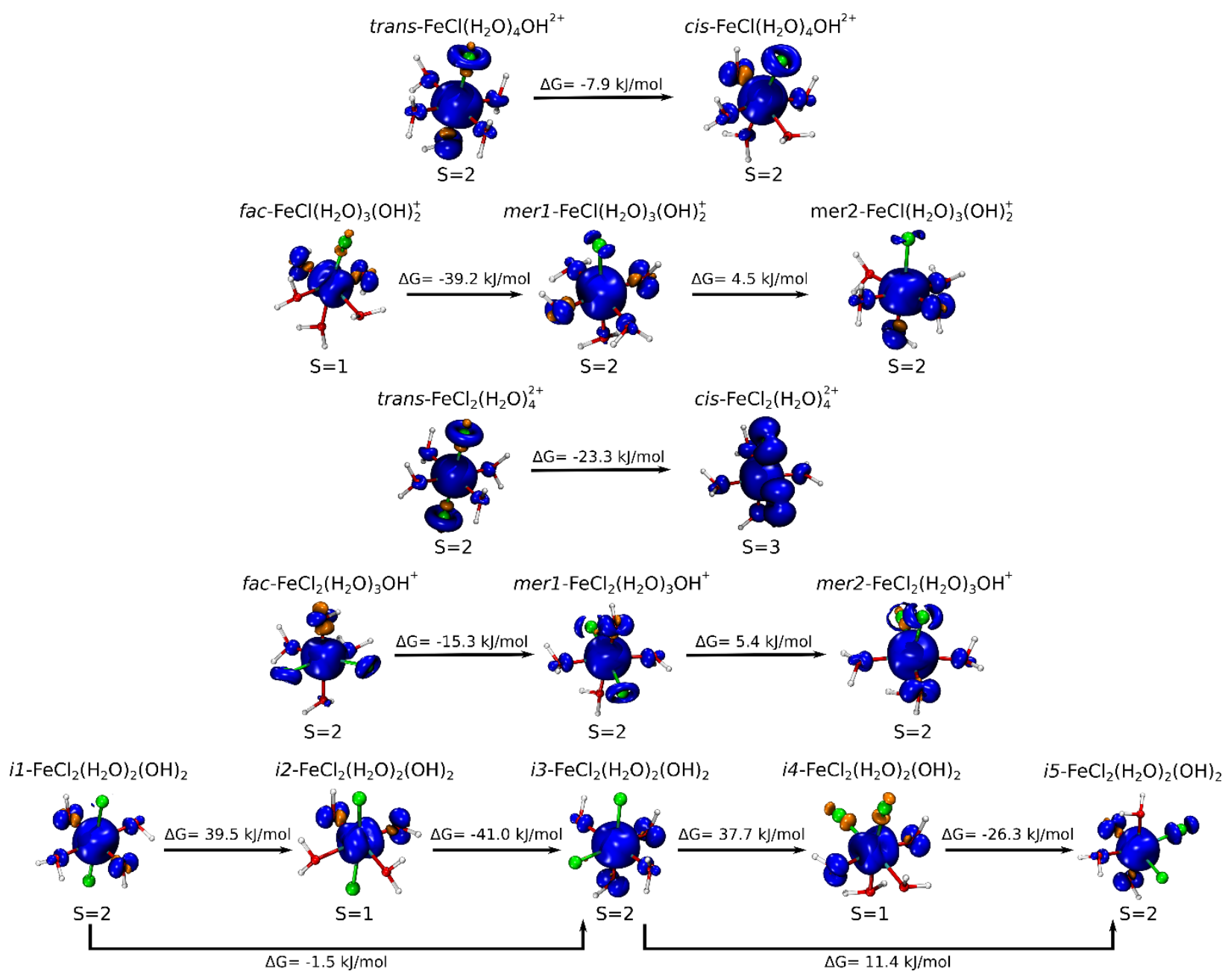

Figure S13. Comparison of the stability of isomers of the Fe-complexes. Only the most stable electronic structure is compared. Isosurfaces highlight the spin density of each Fe-complex. Blue areas indicate regions of increased $\alpha$ spin density while orange highlights regions of increased $\beta$ spin density. Bottom of each complex is shown the total spin $\mathrm{S}$ of the system. 


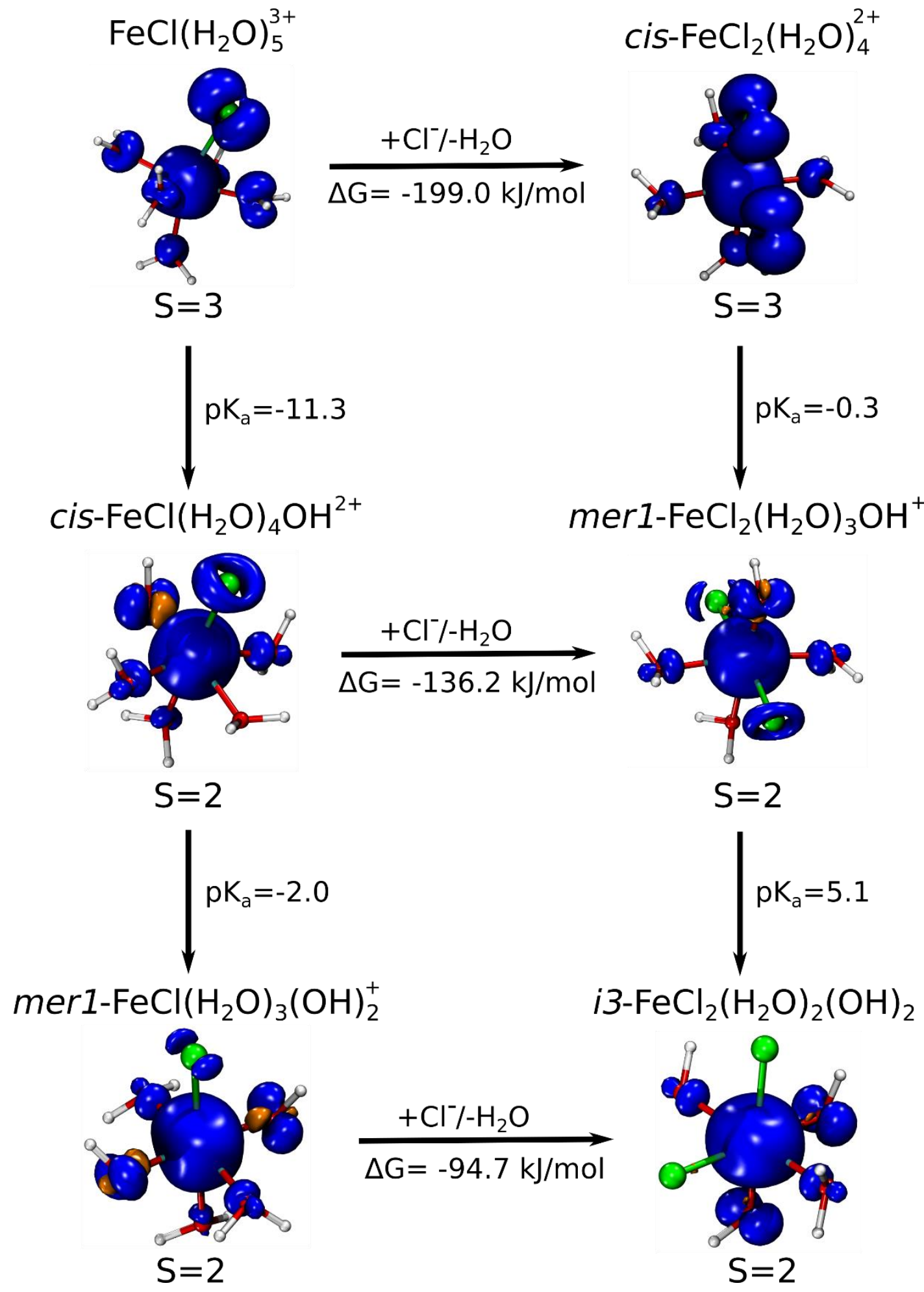

Figure S14. Spin density of each Fe-complex for the most stable isomer and electronic structure. Blue areas indicate regions of increased $\alpha$ spin density while orange highlights regions of increased $\beta$ spin density. Furthermore, $p K_{a}$ values and free reaction enthalpy $\Delta G$ for exchange of a water ligand by a chloride anion. 

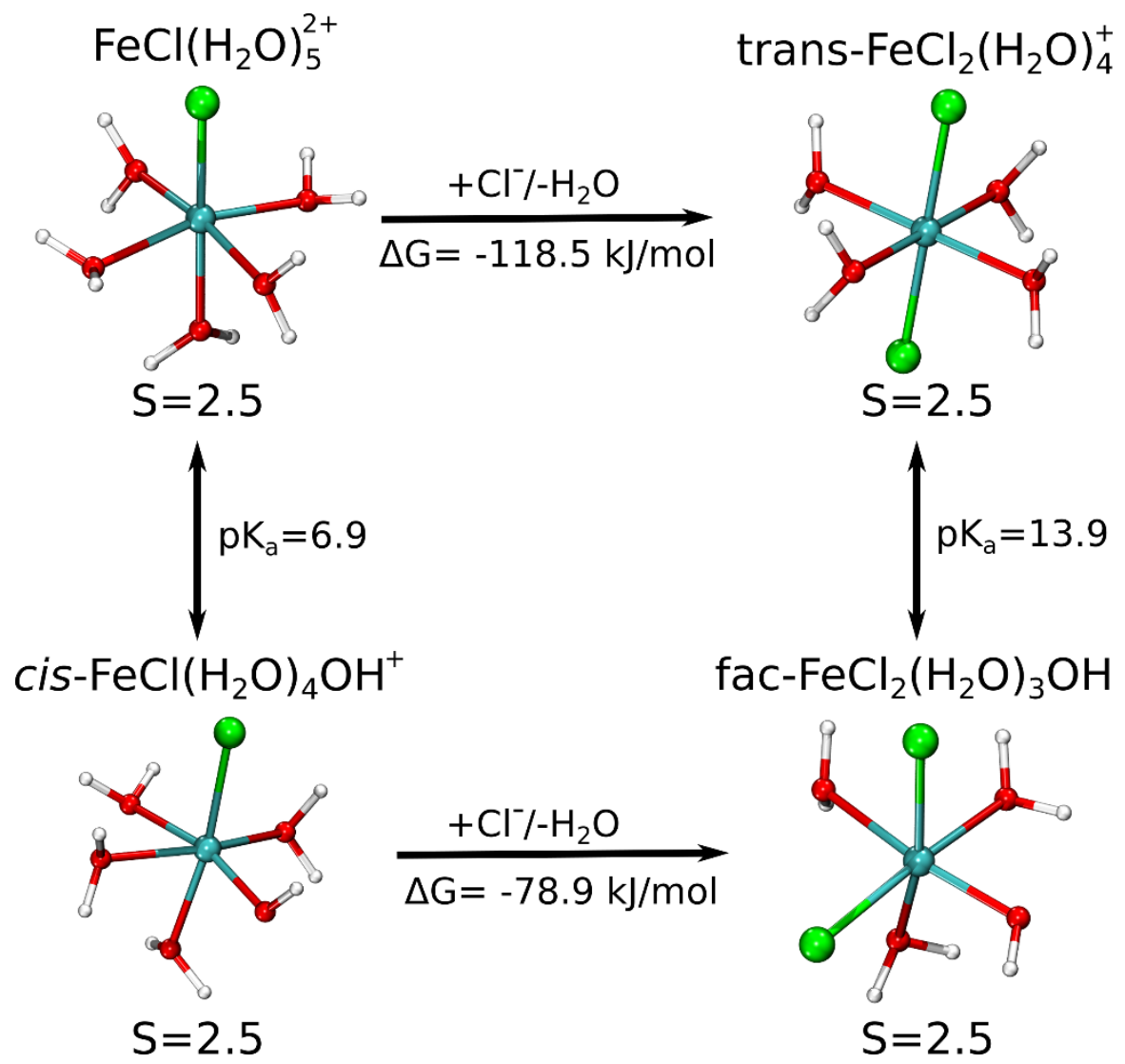

Figure S15. Comparison of the stability of isomers of the Fe(III)-complex before the oxidation. Only the most stable electronic structure is compared. Furthermore, $p K a$ values and free reaction enthalpy $\Delta G$ for exchange of a water ligand by a chloride anion. 


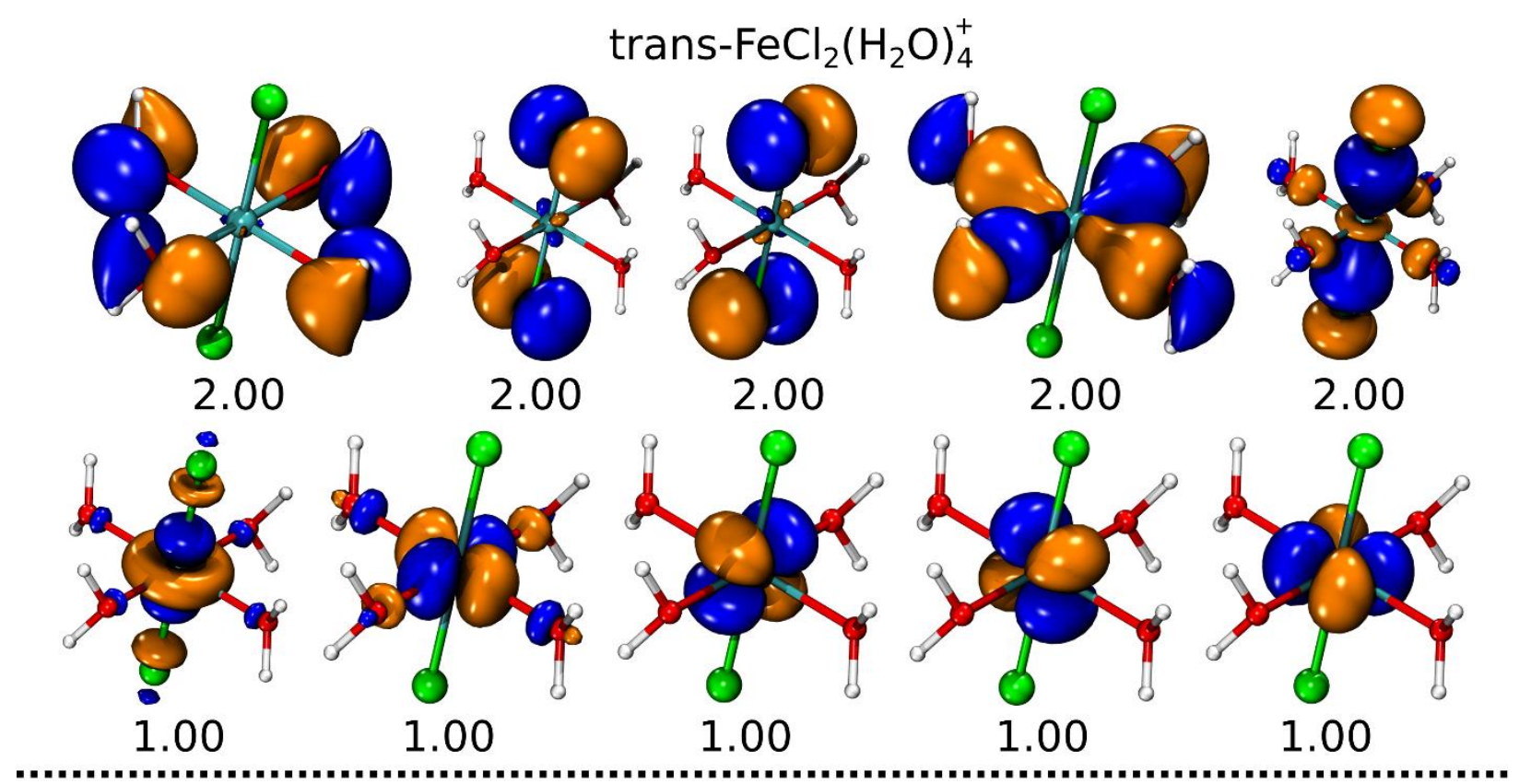

merl- $-\mathrm{FeCl}_{2}\left(\mathrm{H}_{2} \mathrm{O}\right)_{3} \mathrm{OH}^{+}$

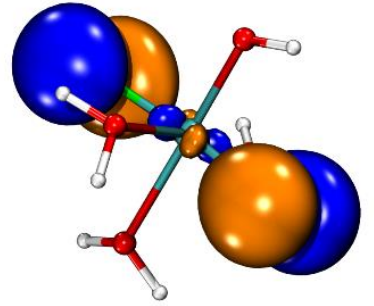

2.00

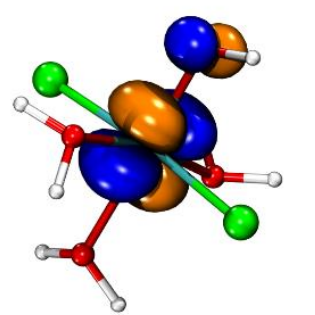

1.03

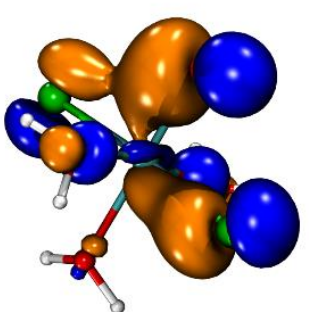

2.00

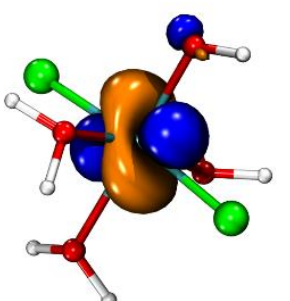

1.00

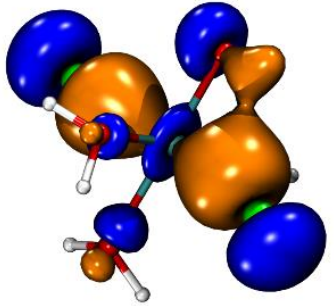

1.99

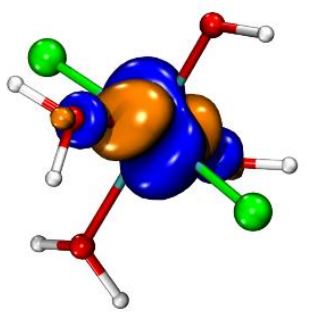

1.00

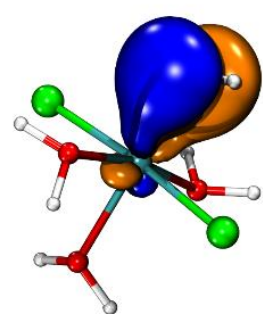

1.97

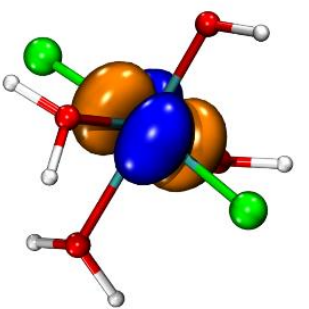

1.00

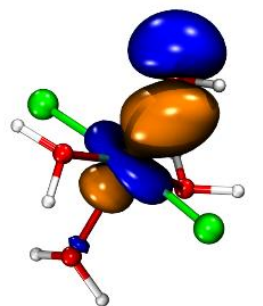

1.56

Figure S16. Natural orbitals and occupation numbers of the CASSCF calculations of trans$\mathrm{FeCl}_{2}\left(\mathrm{H}_{2} \mathrm{O}\right)_{4}{ }^{+}$(top, $\mathrm{S}=2.5, \quad \mathrm{CASSCF}(15,10)$ ) and merl- $\mathrm{FeCl}_{2}\left(\mathrm{H}_{2} \mathrm{O}\right)_{3} \mathrm{OH}^{+}$(bottom, $\mathrm{S}=2$, $\operatorname{CASSCF}(14,10))$ 


\section{Tables of Reactions in Kinetic Model}

The kinetic model used in this report to compute the concentrations of the radiolysis products was adapted from the model of Schneider et. al. ${ }^{7}$ The yield of the primary products $\left(\mathrm{e}^{-}, \mathrm{H}, \mathrm{OH}, \mathrm{H}_{2}\right.$, $\mathrm{H}_{2} \mathrm{O}_{2}, \mathrm{H}^{+}, \mathrm{HO}_{2}$ ) are determined by the G-values derived from previous pulse radiolysis experiments. The 132 kinetic reactions between the 36 species account for the concentration of all species over time. Tables S1 to $\mathbf{S 6}$ show all the reactions used in the kinetic model. All rate constants have units $\mathrm{M}^{-1} \mathrm{~s}^{-1}$ unless otherwise noted.

Table S1. Water Radiolysis Equilibria

\section{Equilibria}

Number

\begin{tabular}{|c|c|}
\hline & $\mathrm{H}_{2} \mathrm{O} \leftrightarrow \mathrm{H}^{+}+\mathrm{OH}^{-}$ \\
\hline 0 & $\mathrm{H}_{2} \mathrm{O}_{2} \leftrightarrow \mathrm{H}^{+}+\mathrm{HO}_{2}$ \\
\hline & $\mathrm{OH}^{\bullet} \leftrightarrow \mathrm{H}^{+}+\mathrm{O}^{\bullet^{-}}$ \\
\hline & $\begin{aligned} \mathrm{HO}_{2}{ }^{\bullet} & \leftrightarrow \mathrm{H}^{+}+\mathrm{O}_{2}^{\bullet-} \\
\mathrm{H}^{\bullet} & \leftrightarrow \mathrm{H}^{+}+\mathrm{e}^{-}\end{aligned}$ \\
\hline
\end{tabular}

pKa

13.999

4.57

9.77
Reference

Table S2. Water Radiolysis Reactions

\begin{tabular}{|c|c|c|c|}
\hline $\begin{array}{l}\text { Reaction } \\
\text { Number }\end{array}$ & Reaction & Rate Constant & Reference \\
\hline 1 & $\mathrm{H}^{+}+\mathrm{OH}^{-} \rightarrow \mathrm{H}_{2} \mathrm{O}$ & $1.4 \times 10^{11}$ & $\left({ }^{7}\right)$ \\
\hline 2 & $\mathrm{H}_{2} \mathrm{O} \rightarrow \mathrm{H}^{+}+\mathrm{OH}^{-}$ & $k_{1} \times K_{1} s^{-1}$ & $\left(7^{7}\right)$ \\
\hline 3 & $\mathrm{H}_{2} \mathrm{O}_{2} \rightarrow \mathrm{H}^{+}+\mathrm{HO}_{2}^{-}$ & $k_{4} \times K_{2} s^{-1}$ & $\left({ }^{7}\right)$ \\
\hline 4 & $\mathrm{H}^{+}+\mathrm{HO}_{2}^{-} \rightarrow \mathrm{H}_{2} \mathrm{O}_{2}$ & $5 \times 10^{10}$ & $\left({ }^{7}\right)$ \\
\hline 5 & $\mathrm{H}_{2} \mathrm{O}_{2}+\mathrm{OH}^{-} \rightarrow \mathrm{HO}_{2}^{-}+\mathrm{H}_{2} \mathrm{O}$ & $1.3 \times 10^{10}$ & $\left({ }^{7}\right)$ \\
\hline 6 & $\mathrm{HO}_{2}^{-}+\mathrm{H}_{2} \mathrm{O} \rightarrow \mathrm{H}_{2} \mathrm{O}_{2}+\mathrm{OH}^{-}$ & $k_{5} \times \frac{K_{1}}{K_{2}} s^{-1}$ & $\left({ }^{7}\right)$ \\
\hline 7 & $\mathrm{e}^{-}+\mathrm{H}_{2} \mathrm{O} \rightarrow \mathrm{H}^{\bullet}+\mathrm{OH}^{-}$ & $1.58 \times 10^{-9}$ & $\left({ }^{7}\right)$ \\
\hline 8 & $\mathrm{H}^{\bullet}+\mathrm{OH}^{-} \rightarrow \mathrm{H}_{2} \mathrm{O}+\mathrm{e}^{-}$ & $2.2 \times 10^{7}$ & $\left(7^{7}\right)$ \\
\hline 9 & $\mathrm{H}^{\bullet} \rightarrow \mathrm{e}^{-}+\mathrm{H}^{+}$ & $k_{10} \times K_{5} s^{-1}$ & $\left(7^{7}\right)$ \\
\hline 10 & $\mathrm{e}^{-}+\mathrm{H}^{+} \rightarrow \mathrm{H}^{\bullet}$ & $2.3 \times 10^{10}$ & $\left({ }^{7}\right)$ \\
\hline 11 & $\mathrm{OH}^{-}+\cdot{ }^{\cdot} \mathrm{OH} \rightarrow \mathrm{H}_{2} \mathrm{O}+\mathrm{O}^{\cdot-}$ & $1.3 \times 10^{10}$ & $\left({ }^{7}\right)$ \\
\hline 12 & $\mathrm{O}^{--}+\mathrm{H}_{2} \mathrm{O} \rightarrow \mathrm{OH}^{-}+{ }^{\bullet} \mathrm{OH}$ & $k_{11} \times \frac{K_{1}}{K_{3}}$ & $\left({ }^{7}\right)$ \\
\hline 13 & $\cdot \mathrm{OH} \rightarrow \mathrm{O}^{\bullet-}+\mathrm{H}^{+}$ & $k_{14} \times K_{3} s^{-1}$ & $\left({ }^{7}\right)$ \\
\hline 14 & $\mathrm{O}^{\bullet-}+\mathrm{H}^{+} \rightarrow{ }^{\bullet} \mathrm{OH}$ & $1 \times 10^{11}$ & $\left({ }^{7}\right)$ \\
\hline 15 & $\mathrm{HO}_{2}^{\cdot} \rightarrow \mathrm{H}^{+}+\mathrm{O}_{2}^{\cdot-}$ & $k_{16} \times K_{4} s^{-1}$ & $\left(7^{7}\right)$ \\
\hline 16 & $\mathrm{H}^{+}+\mathrm{O}_{2}^{\cdot-} \rightarrow \mathrm{HO}_{2}^{\cdot}$ & $5 \times 10^{10}$ & $(7)$ \\
\hline 17 & $\mathrm{HO}_{2}^{\bullet}+\cdot \mathrm{OH} \rightarrow \mathrm{H}^{+}+\mathrm{O}_{2}^{\cdot-}$ & $5 \times 10^{10}$ & $\left(7^{7}\right)$ \\
\hline
\end{tabular}




\begin{tabular}{|c|c|c|c|}
\hline 18 & $\mathrm{O}_{2}+\mathrm{H}_{2} \mathrm{O} \rightarrow \mathrm{HO}_{2}+\mathrm{OH}^{-}$ & $k_{17} \times \frac{\Lambda_{1}}{K_{4}}$ & \\
\hline 19 & $\mathrm{e}^{-}+{ }^{\bullet} \mathrm{OH} \rightarrow \mathrm{OH}^{-}$ & $3 \times 10^{10}$ & $\left({ }^{7}\right)$ \\
\hline 20 & $\mathrm{e}^{-}+\mathrm{H}_{2} \mathrm{O}_{2} \rightarrow \cdot \mathrm{OH}+\mathrm{OH}^{-}$ & $1.1 \times 10^{10}$ & $\left({ }^{7}\right)$ \\
\hline 21 & $\mathrm{e}^{-}+\mathrm{O}_{2}^{\cdot-}+\mathrm{H}_{2} \mathrm{O} \rightarrow \mathrm{HO}_{2}^{-}+\mathrm{OH}^{-}$ & $1.3 \times 10^{10} M^{-2} s^{-1}$ & $\left({ }^{7}\right)$ \\
\hline 22 & $\mathrm{e}^{-}+\mathrm{HO}_{2}^{\bullet} \rightarrow \mathrm{HO}_{2}^{-}$ & $2 \times 10^{10}$ & $\left({ }^{7}\right)$ \\
\hline 23 & $\mathrm{e}^{-}+\mathrm{O}_{2} \rightarrow \mathrm{O}_{2}^{\cdot-}$ & $1.9 \times 10^{10}$ & $\left({ }^{7}\right)$ \\
\hline 24 & $2 \mathrm{e}^{-}+2 \mathrm{H}_{2} \mathrm{O} \rightarrow \mathrm{H}_{2}+2 \mathrm{OH}^{-}$ & $5.5 \times 10^{9} M^{-3} S^{-1}$ & $\left({ }^{7}\right)$ \\
\hline 25 & $\mathrm{e}^{-}+\mathrm{H}^{\bullet}+\mathrm{H}_{2} \mathrm{O} \rightarrow \mathrm{H}_{2}+\mathrm{OH}^{-}$ & $2.5 \times 10^{10} M^{-2} S^{-1}$ & $\left({ }^{7}\right)$ \\
\hline 26 & $\mathrm{e}^{-}+\mathrm{HO}_{2}^{-} \rightarrow \mathrm{O}^{\bullet-}+\mathrm{OH}^{-}$ & $3.5 \times 10^{9}$ & $\left({ }^{7}\right)$ \\
\hline 27 & $\mathrm{e}^{-}+\mathrm{H}_{2} \mathrm{O}+\mathrm{O}^{\bullet-} \rightarrow 2 \mathrm{OH}^{-}$ & $2.2 \times 10^{10}$ & $\left({ }^{7}\right)$ \\
\hline 28 & $\mathrm{e}^{-}+\mathrm{O}_{3}^{-}+\mathrm{H}_{2} \mathrm{O} \rightarrow \mathrm{O}_{2}+2 \mathrm{OH}^{-}$ & $1.6 \times 10^{10} M^{-2} S^{-1}$ & $\left({ }^{7}\right)$ \\
\hline 29 & $\mathrm{e}^{-}+\mathrm{O}_{3} \rightarrow \mathrm{O}_{3}^{-}$ & $3.6 \times 10^{10}$ & $\left({ }^{7}\right)$ \\
\hline 30 & $\mathrm{H}^{\bullet}+\mathrm{H}_{2} \mathrm{O} \rightarrow \mathrm{H}_{2}+{ }^{\bullet} \mathrm{OH}$ & $1.1 \times 10^{1}$ & $\left({ }^{7}\right)$ \\
\hline 31 & $\mathrm{H}^{\bullet}+\mathrm{O}^{\bullet-} \rightarrow \mathrm{OH}^{-}$ & $1 \times 10^{10}$ & $\left({ }^{7}\right)$ \\
\hline 32 & $\mathrm{H}^{\bullet}+\mathrm{HO}_{2}^{-} \rightarrow{ }^{\bullet} \mathrm{OH}+\mathrm{OH}^{-}$ & $9 \times 10^{7}$ & $\left({ }^{7}\right)$ \\
\hline 33 & $\mathrm{H}^{\bullet}+\mathrm{O}_{3}^{-} \rightarrow \mathrm{OH}^{-}+\mathrm{O}_{2}$ & $1 \times 10^{10}$ & $\left({ }^{7}\right)$ \\
\hline 34 & $2 \mathrm{H}^{\bullet} \rightarrow \mathrm{H}_{2}$ & $7.8 \times 10^{9}$ & $\left({ }^{7}\right)$ \\
\hline 35 & $\mathrm{H}^{\bullet}+{ }^{\bullet} \mathrm{OH} \rightarrow \mathrm{H}_{2} \mathrm{O}$ & $7 \times 10^{9}$ & $\left({ }^{7}\right)$ \\
\hline 36 & $\mathrm{H}^{\bullet}+\mathrm{H}_{2} \mathrm{O}_{2} \rightarrow{ }^{\bullet} \mathrm{OH}+\mathrm{H}_{2} \mathrm{O}$ & $9 \times 10^{7}$ & $\left({ }^{7}\right)$ \\
\hline 37 & $\mathrm{H}^{\bullet}+\mathrm{O}_{2} \rightarrow \mathrm{HO}_{2}^{\bullet}$ & $2.1 \times 10^{10}$ & $\left({ }^{7}\right)$ \\
\hline 38 & $\mathrm{H}^{\bullet}+\mathrm{HO}_{2}^{\bullet} \rightarrow \mathrm{H}_{2} \mathrm{O}_{2}$ & $1.8 \times 10^{10}$ & $\left({ }^{7}\right)$ \\
\hline 39 & $\mathrm{H}^{\bullet}+\mathrm{O}_{2}^{--} \rightarrow \mathrm{HO}_{2}^{-}$ & $1.8 \times 10^{10}$ & $\left({ }^{7}\right)$ \\
\hline 40 & $\mathrm{H}^{\bullet}+\mathrm{O}_{3} \rightarrow \mathrm{HO}_{3}^{\bullet}$ & $3.8 \times 10^{10}$ & $\left({ }^{7}\right)$ \\
\hline 41 & $\bullet \mathrm{OH}+{ }^{\bullet} \mathrm{OH} \rightarrow \mathrm{H}_{2} \mathrm{O}_{2}$ & $3.6 \times 10^{9}$ & $\left(7^{7}\right)$ \\
\hline 42 & ${ }^{\bullet} \mathrm{OH}+\mathrm{HO}_{2}{ }^{\bullet} \rightarrow \mathrm{H}_{2} \mathrm{O}+\mathrm{O}_{2}$ & $6 \times 10^{9}$ & $\left({ }^{7}\right)$ \\
\hline 43 & $\cdot \mathrm{OH}+\mathrm{O}_{2}^{\cdot-} \rightarrow \mathrm{OH}^{-}+\mathrm{O}_{2}$ & $8.2 \times 10^{9}$ & $\left({ }^{7}\right)$ \\
\hline 44 & $\cdot \mathrm{OH}+\mathrm{H}_{2} \rightarrow \mathrm{H}^{\bullet}+\mathrm{H}_{2} \mathrm{O}$ & $4.3 \times 10^{7}$ & $\left({ }^{7}\right)$ \\
\hline 45 & $\cdot \mathrm{OH}+\mathrm{H}_{2} \mathrm{O}_{2} \rightarrow \mathrm{HO}_{2}^{\bullet}+\mathrm{H}_{2} \mathrm{O}$ & $2.7 \times 10^{7}$ & $\left({ }^{7}\right)$ \\
\hline 46 & $\cdot \mathrm{OH}+\mathrm{O}^{\bullet-} \rightarrow \mathrm{HO}_{2}^{-}$ & $2.5 \times 10^{10}$ & $\left({ }^{7}\right)$ \\
\hline 47 & ${ }^{\cdot} \mathrm{OH}+\mathrm{HO}_{2}^{-} \rightarrow \mathrm{HO}_{2}^{\cdot}+\mathrm{OH}^{-}$ & $7.5 \times 10^{9}$ & $\left({ }^{7}\right)$ \\
\hline 48 & $\cdot \mathrm{OH}+\mathrm{O}_{3}^{-} \rightarrow \mathrm{O}_{3}+\mathrm{OH}^{-}$ & $2.6 \times 10^{9}$ & $\left({ }^{7}\right)$ \\
\hline 49 & $\cdot \mathrm{OH}+\mathrm{O}_{3}^{-} \rightarrow 2 \mathrm{O}_{2}^{-}+\mathrm{H}^{+}$ & $6 \times 10^{9}$ & $\left({ }^{7}\right)$ \\
\hline 50 & $\cdot \mathrm{OH}+\mathrm{O}_{3} \rightarrow \mathrm{HO}_{2}^{\bullet}+\mathrm{O}_{2}$ & $1.1 \times 10^{8}$ & $\left({ }^{7}\right)$ \\
\hline 51 & $\mathrm{HO}_{2}{ }^{-}+\mathrm{O}_{2}^{-} \rightarrow \mathrm{HO}_{2}^{-}+\mathrm{O}_{2}$ & $8 \times 10^{7}$ & $\left({ }^{7}\right)$ \\
\hline 52 & $2 \mathrm{HO}_{2}{ }^{\bullet} \rightarrow \mathrm{H}_{2} \mathrm{O}_{2}+\mathrm{O}_{2}$ & $7 \times 10^{5}$ & $\left({ }^{7}\right)$ \\
\hline 53 & $\mathrm{HO}_{2}^{\bullet}+\mathrm{O}^{\bullet-} \rightarrow \mathrm{O}_{2}+\mathrm{OH}^{-}$ & $6 \times 10^{9}$ & $\left({ }^{7}\right)$ \\
\hline 54 & $\mathrm{HO}_{2}^{\bullet}+\mathrm{H}_{2} \mathrm{O}_{2} \rightarrow{ }^{\bullet} \mathrm{OH}+\mathrm{O}_{2}+\mathrm{H}_{2} \mathrm{O}$ & $5 \times 10^{-1}$ & $\left({ }^{7}\right)$ \\
\hline 55 & $\mathrm{HO}_{2}{ }^{-}+\mathrm{HO}_{2}^{-} \rightarrow{ }^{\bullet} \mathrm{OH}+\mathrm{O}_{2}+\mathrm{OH}^{-}$ & $5 \times 10^{-1}$ & $\left({ }^{7}\right)$ \\
\hline 56 & $\mathrm{HO}_{2}^{\bullet}+\mathrm{O}_{3}^{-} \rightarrow 2 \mathrm{O}_{2}+\mathrm{OH}^{-}$ & $6 \times 10^{9}$ & $\left({ }^{7}\right)$ \\
\hline 57 & $\mathrm{HO}_{2}^{\bullet}+\mathrm{O}_{3} \rightarrow \mathrm{HO}_{3}+\mathrm{O}_{2}$ & $5 \times 10^{8}$ & $\left({ }^{7}\right)$ \\
\hline 58 & $2 \mathrm{O}_{2}^{\cdot-}+2 \mathrm{H}_{2} \mathrm{O} \rightarrow \mathrm{H}_{2} \mathrm{O}_{2}+\mathrm{O}_{2}+2 \mathrm{OH}^{-}$ & $1 \times 10^{2} M^{-3} s^{-1}$ & $\left({ }^{7}\right)$ \\
\hline 59 & $\mathrm{O}_{2}^{\cdot-}+\mathrm{O}^{\bullet-}+\mathrm{H}_{2} \mathrm{O} \rightarrow \mathrm{O}_{2}+2 \mathrm{OH}^{-}$ & $6 \times 10^{8} M^{-2} s^{-1}$ & $\left({ }^{7}\right)$ \\
\hline 60 & $\mathrm{O}_{2}^{\cdot-}+\mathrm{H}_{2} \mathrm{O}_{2} \rightarrow{ }^{\bullet} \mathrm{OH}+\mathrm{O}_{2}+\mathrm{OH}^{-}$ & $1.3 \times 10^{-1}$ & $\left({ }^{7}\right)$ \\
\hline 61 & $\mathrm{O}_{2}^{\cdot-}+\mathrm{HO}_{2}^{\cdot-} \rightarrow \mathrm{O}^{\bullet-}+\mathrm{O}_{2}+\mathrm{OH}^{-}$ & $1.3 \times 10^{-1}$ & $\left({ }^{7}\right)$ \\
\hline
\end{tabular}




\begin{tabular}{|c|c|c|}
\hline 62 & $\mathrm{O}_{2}^{\cdot-}+\mathrm{O}_{3}^{-}+\mathrm{H}_{2} \mathrm{O} \rightarrow 2 \mathrm{O}_{2}+2 \mathrm{OH}^{-}$ & $1 \times 10^{4}$ \\
\hline 63 & $\mathrm{O}_{2}^{\bullet-}+\mathrm{O}_{3} \rightarrow \mathrm{O}_{3}^{-}+\mathrm{O}_{2}$ & $1.5 \times 10^{9}$ \\
\hline 64 & $20^{\bullet-}+\mathrm{H}_{2} \mathrm{O} \rightarrow \mathrm{HO}_{2}^{-}+\mathrm{OH}^{-}$ & $1 \times 10^{9} M^{-2} s^{-1}$ \\
\hline 65 & $\mathrm{O}^{\bullet-}+\mathrm{O}_{2} \rightarrow \mathrm{O}_{3}^{-}$ & $3.6 \times 10^{9}$ \\
\hline 66 & $\mathrm{O}^{\bullet-}+\mathrm{H}_{2} \rightarrow \mathrm{H}^{\bullet}+\mathrm{OH}^{-}$ & $8 \times 10^{7}$ \\
\hline 67 & $\mathrm{O}^{\bullet-}+\mathrm{H}_{2} \mathrm{O}_{2} \rightarrow \mathrm{O}_{2}^{\cdot-}+\mathrm{H}_{2} \mathrm{O}$ & $5 \times 10^{8}$ \\
\hline 68 & $\mathrm{O}^{\bullet-}+\mathrm{HO}_{2}^{\cdot-} \rightarrow \mathrm{O}_{2}^{-}+\mathrm{OH}^{-}$ & $4 \times 10^{8}$ \\
\hline 69 & $\mathrm{O}^{\bullet-}+\mathrm{O}_{3}^{-} \rightarrow \mathrm{O}_{2}^{\cdot-}+\mathrm{O}_{2}^{\bullet-}$ & $7 \times 10^{8}$ \\
\hline 70 & $\mathrm{O}^{\bullet-}+\mathrm{O}_{3} \rightarrow \mathrm{O}_{2}+\mathrm{O}_{2}^{\bullet-}$ & $5 \times 10^{9}$ \\
\hline 71 & $\mathrm{O}_{3}^{-} \rightarrow \mathrm{O}_{2}+\mathrm{O}^{\bullet-}$ & $3.3 \times 10^{3} s^{-1}$ \\
\hline 72 & $\mathrm{O}_{3}^{-}+\mathrm{H}^{+} \rightarrow \mathrm{O}_{2}+{ }^{\bullet} \mathrm{OH}$ & $9 \times 10^{10}$ \\
\hline 73 & $\mathrm{HO}_{3}^{\bullet} \rightarrow \mathrm{O}_{2}+{ }^{\bullet} \mathrm{OH}$ & $1.1 \times 10^{5} s^{-1}$ \\
\hline
\end{tabular}

Table S3. Chlorine Radiolysis Reactions

\begin{tabular}{|c|c|c|c|}
\hline $\begin{array}{l}\text { Reaction } \\
\text { Number }\end{array}$ & Reaction & Rate Constant & Reference \\
\hline 74 & $\mathrm{Cl}^{-}+\cdot \mathrm{OH} \rightarrow \mathrm{ClOH}^{\bullet-}$ & $4.3 \times 10^{9}$ & $\left({ }^{8}\right)$ \\
\hline 75 & $\mathrm{ClOH}^{\bullet-} \rightarrow \mathrm{Cl}^{-}+{ }^{\bullet} \mathrm{OH}$ & $6.1 \times 10^{9} s^{-1}$ & $\left({ }^{8}\right)$ \\
\hline 76 & $\mathrm{ClOH}^{\bullet-}+\mathrm{H}^{+} \rightarrow \mathrm{Cl}^{\bullet}+\mathrm{H}_{2} \mathrm{O}$ & $2.1 \times 10^{10}$ & $\left({ }^{8}\right)$ \\
\hline 77 & $\mathrm{Cl}^{\bullet}+\mathrm{Cl}^{-} \rightarrow \mathrm{Cl}_{2}^{\bullet-}$ & $8.5 \times 10^{9}$ & $\left({ }^{8}\right)$ \\
\hline 78 & $\mathrm{Cl}_{2}^{\cdot-}+\mathrm{e}^{-} \rightarrow 2 \mathrm{Cl}^{-}$ & $1 \times 10^{10}$ & $\left({ }^{8}\right)$ \\
\hline 79 & $\mathrm{Cl}_{2}{ }^{--}+\mathrm{H}^{\bullet} \rightarrow 2 \mathrm{Cl}^{-}+\mathrm{H}^{+}$ & $8 \times 10^{9}$ & $\left({ }^{8}\right)$ \\
\hline 80 & $\mathrm{Cl}^{\bullet}+\mathrm{H}^{\bullet} \rightarrow \mathrm{Cl}^{-}+\mathrm{H}^{+}$ & $1 \times 10^{10}$ & $\left({ }^{8}\right)$ \\
\hline 81 & $\mathrm{Cl}_{2}^{\bullet-} \rightarrow \mathrm{Cl}^{-}+\mathrm{Cl}^{\bullet}$ & $6 \times 10^{4} s^{-1}$ & $\left({ }^{8}\right)$ \\
\hline 82 & $\mathrm{Cl}_{2}+\mathrm{HO}_{2}^{\cdot} \rightarrow \mathrm{O}_{2}+\mathrm{Cl}_{2}^{\cdot-}+\mathrm{H}^{+}$ & $1 \times 10^{9}$ & $\left({ }^{8}\right)$ \\
\hline 83 & $\mathrm{Cl}^{\bullet}+\mathrm{Cl}^{\bullet} \rightarrow \mathrm{Cl}_{2}$ & $8.8 \times 10^{7}$ & $\left({ }^{8}\right)$ \\
\hline 84 & $\mathrm{Cl}^{\bullet}+\mathrm{OH}^{-} \rightarrow \mathrm{ClOH}^{\bullet-}$ & $1.8 \times 10^{10}$ & $\left({ }^{8}\right)$ \\
\hline 85 & $\mathrm{H}_{2} \mathrm{O}_{2}+\mathrm{Cl}_{2}^{\bullet-} \rightarrow \mathrm{HO}_{2}^{\bullet}+2 \mathrm{Cl}^{-}+\mathrm{H}^{+}$ & $1.4 \times 10^{5}$ & $\left({ }^{8}\right)$ \\
\hline 86 & $\mathrm{HO}_{2}^{\bullet}+\mathrm{Cl}_{2}^{\cdot-} \rightarrow \mathrm{O}_{2}+2 \mathrm{Cl}^{-}+\mathrm{H}^{+}$ & $1 \times 10^{9}$ & $\left({ }^{8}\right)$ \\
\hline 87 & $\mathrm{Cl}_{3}^{-}+\mathrm{H}^{\bullet} \rightarrow \mathrm{Cl}^{-}+\mathrm{Cl}_{2}^{\bullet-}+\mathrm{H}^{+}$ & $1 \times 10^{10}$ & $\left({ }^{8}\right)$ \\
\hline 88 & $2 \mathrm{Cl}_{2}^{\cdot-} \rightarrow \mathrm{Cl}_{3}^{-}+\mathrm{Cl}^{-}$ & $2 \times 10^{9}$ & $\left({ }^{8}\right)$ \\
\hline 89 & $\mathrm{Cl}_{3}^{-} \rightarrow \mathrm{Cl}_{2}+\mathrm{Cl}^{-}$ & $5 \times 10^{4} s^{-1}$ & $\left({ }^{8}\right)$ \\
\hline 90 & $\mathrm{Cl}_{2}+\mathrm{Cl}^{-} \rightarrow \mathrm{Cl}_{3}^{-}$ & $1 \times 10^{4}$ & $\left({ }^{8}\right)$ \\
\hline 91 & $\mathrm{e}^{-}+\mathrm{Cl}^{\bullet} \rightarrow \mathrm{Cl}^{-}$ & $1 \times 10^{10}$ & $\left({ }^{8}\right)$ \\
\hline 92 & $\mathrm{e}^{-}+\mathrm{Cl}_{3}^{-} \rightarrow \mathrm{Cl}_{2}^{\cdot-}+\mathrm{Cl}^{-}$ & $3 \times 10^{10}$ & $\left({ }^{8}\right)$ \\
\hline 93 & $\mathrm{Cl}^{\bullet}+\mathrm{H}_{2} \mathrm{O}_{2} \rightarrow \mathrm{Cl}^{-}+\mathrm{HO}_{2}^{\bullet}+\mathrm{H}^{+}$ & $2 \times 10^{9}$ & $\left({ }^{8}\right)$ \\
\hline 94 & $\mathrm{ClOH}^{\bullet-} \rightarrow \mathrm{Cl}^{\bullet}+\mathrm{OH}^{-}$ & $2.3 \times 10^{1} s^{-1}$ & $\left({ }^{8}\right)$ \\
\hline 95 & $\mathrm{Cl}^{\bullet}+\mathrm{Cl}_{2}^{\bullet-} \rightarrow \mathrm{Cl}_{3}^{-}$ & $6.3 \times 10^{8}$ & $\left({ }^{9}\right)$ \\
\hline
\end{tabular}

Table S4. Bromine Radiolysis Reactions 


\begin{tabular}{|c|c|c|c|}
\hline $\begin{array}{l}\text { Reaction } \\
\text { Number }\end{array}$ & Reaction & Rate Constant & Referen \\
\hline 96 & $\mathrm{Br}^{-}+\cdot \mathrm{OH} \rightarrow \mathrm{BrOH}^{\bullet-}$ & $1.1 \times 10^{10}$ & $\left({ }^{10}\right)$ \\
\hline 97 & $\mathrm{BrOH}^{\bullet-} \rightarrow \mathrm{Br}^{-}+{ }^{\bullet} \mathrm{OH}$ & $3.3 \times 10^{7} s^{-1}$ & $\left({ }^{10}\right)$ \\
\hline 98 & $\mathrm{Br}^{-}+\mathrm{Br} \rightarrow \mathrm{Br}_{2}^{\bullet-}$ & $1.2 \times 10^{10}$ & $\left({ }^{11}\right)$ \\
\hline 99 & $\mathrm{Br}_{2}^{\cdot-} \rightarrow \mathrm{Br}^{-}+\mathrm{Br}$ & $1.9 \times 10^{4} s^{-1}$ & $\left({ }^{11}\right)$ \\
\hline 100 & $\mathrm{BrOH}^{\bullet-}+\mathrm{H}^{+} \rightarrow \mathrm{Br}^{\bullet}+\mathrm{H}_{2} \mathrm{O}$ & $4.4 \times 10^{10}$ & $\left({ }^{10}\right)$ \\
\hline 101 & $\mathrm{Br}^{\bullet}+\mathrm{OH}^{-} \rightarrow \mathrm{BrOH}^{\bullet-}$ & $1.3 \times 10^{10}$ & $\left({ }^{12}\right)$ \\
\hline 102 & $\mathrm{Br}_{2}^{\cdot-}+\mathrm{H}^{\bullet} \rightarrow \mathrm{H}^{+}+2 \mathrm{Br}^{-}$ & $1.4 \times 10^{10}$ & $\left({ }^{13}\right)$ \\
\hline 103 & $\mathrm{Br}_{2}^{\cdot-}+\mathrm{e}^{-} \rightarrow 2 \mathrm{Br}^{-}$ & $1.1 \times 10^{10}$ & $\left({ }^{13}\right)$ \\
\hline 104 & $\mathrm{Br}_{3}^{-}+\mathrm{H}^{\bullet} \rightarrow \mathrm{H}^{+}+\mathrm{Br}_{2}^{\bullet-}+\mathrm{Br}^{-}$ & $1.2 \times 10^{10}$ & $\left({ }^{13}\right)$ \\
\hline 105 & $\mathrm{Br}_{3}^{-}+\mathrm{e}^{-} \rightarrow \mathrm{Br}_{2}^{\cdot-}+\mathrm{Br}^{-}$ & $2.7 \times 10^{10}$ & $\left({ }^{13}\right)$ \\
\hline 106 & $\mathrm{Br}_{2}+\mathrm{Br}^{-} \rightarrow \mathrm{Br}_{3}^{-}$ & $9.6 \times 10^{8}$ & $\left({ }^{14}\right)$ \\
\hline 107 & $\mathrm{Br}_{3}^{-} \rightarrow \mathrm{Br}_{2}+\mathrm{Br}^{-}$ & $5.5 \times 10^{7} s^{-1}$ & $\left({ }^{14}\right)$ \\
\hline 108 & $\mathrm{Br}_{2}^{\cdot-}+\mathrm{H}_{2} \mathrm{O}_{2} \rightarrow 2 \mathrm{Br}^{-}+\mathrm{HO}_{2}{ }^{\bullet}+\mathrm{H}^{+}$ & $5 \times 10^{2}$ & $\left({ }^{15}\right)$ \\
\hline 109 & $\mathrm{BrOH}^{\bullet-} \rightarrow \mathrm{Br}^{\bullet}+\mathrm{OH}^{-}$ & $4.2 \times 10^{6} s^{-1}$ & $\left({ }^{10}\right)$ \\
\hline 110 & $\mathrm{Br}_{2}+\mathrm{HO}_{2}^{\bullet} \rightarrow \mathrm{Br}_{2}^{\cdot-}+\mathrm{H}^{+}+\mathrm{O}_{2}$ & $1.1 \times 10^{8}$ & $(16)$ \\
\hline 111 & $\mathrm{Br}_{2}^{\bullet-}+\mathrm{HO}_{2}^{\bullet} \rightarrow \mathrm{H}^{+}+2 \mathrm{Br}^{-}+\mathrm{O}_{2}$ & $4.6 \times 10^{9}$ & $\left({ }^{17}\right)$ \\
\hline
\end{tabular}

Table S5. Iodine Radiolysis Reactions

\begin{tabular}{|c|c|c|}
\hline $\begin{array}{l}\text { Reaction } \\
\text { Number }\end{array}$ & Reaction & Rate Constant \\
\hline 112 & $\mathrm{I}^{-}+{ }^{\bullet} \mathrm{OH} \rightarrow \mathrm{HOI}^{\bullet-}$ & $1.6 \times 10^{10}$ \\
\hline 113 & $\mathrm{I}^{-}+\mathrm{I}^{\bullet} \rightarrow \mathrm{I}_{2}^{\bullet-}$ & $9.1 \times 10^{9}$ \\
\hline 114 & $\mathrm{I}_{2}^{\bullet-}+\mathrm{I}^{\bullet} \rightarrow \mathrm{I}_{3}^{-}$ & $6.5 \times 10^{9}$ \\
\hline 115 & $\mathrm{I}_{3}^{-}+\mathrm{e}^{-} \rightarrow \mathrm{I}_{2}^{\cdot-}+\mathrm{I}^{-}$ & $3.5 \times 10^{10}$ \\
\hline 116 & $2 \mathrm{I}_{2}^{\cdot-} \rightarrow \mathrm{I}^{-}+\mathrm{I}_{3}^{-}$ & $2.5 \times 10^{9}$ \\
\hline 117 & $\mathrm{I}_{2}^{\cdot-}+\mathrm{H}^{\bullet} \rightarrow 2 \mathrm{I}^{-}+\mathrm{H}^{+}$ & $1.8 \times 10^{7}$ \\
\hline 118 & $\mathrm{I}_{2}+\mathrm{H}^{\bullet} \rightarrow \mathrm{H}^{+}+\mathrm{I}_{2}^{\bullet-}$ & $3.5 \times 10^{10}$ \\
\hline 119 & $\mathrm{I}_{3}^{-}+\mathrm{H}^{\bullet} \rightarrow \mathrm{H}^{+}+\mathrm{I}_{2}^{\cdot-}+\mathrm{I}^{-}$ & $3.5 \times 10^{10}$ \\
\hline 120 & $\mathrm{I}_{2}^{\cdot-}+\mathrm{HO}_{2}^{\cdot} \rightarrow \mathrm{I}_{2}+\mathrm{HO}_{2}^{-}$ & $4 \times 10^{9}$ \\
\hline 121 & $2 \mathrm{I}^{\bullet} \rightarrow \mathrm{I}_{2}$ & $1.1 \times 10^{10}$ \\
\hline 122 & $\mathrm{I}_{3}^{-}+\mathrm{O}_{2}^{\cdot-} \rightarrow \mathrm{O}_{2}+\mathrm{I}_{2}^{\cdot-}+\mathrm{I}^{-}$ & $2.5 \times 10^{8}$ \\
\hline 123 & $\mathrm{I}_{2}+\mathrm{HO}_{2}^{\cdot} \rightarrow \mathrm{I}_{2}^{{ }^{-}}+\mathrm{H}^{+}+\mathrm{O}_{2}$ & $1.8 \times 10^{7}$ \\
\hline 124 & $\mathrm{I}^{\bullet}+\mathrm{OH}^{-} \rightarrow \mathrm{HOI}^{\bullet-}$ & $1.6 \times 10^{8}$ \\
\hline 125 & $\mathrm{HOI}^{\bullet-} \rightarrow \mathrm{I}^{\bullet}+\mathrm{OH}^{-}$ & $3.5 \times 10^{7} s^{-1}$ \\
\hline 126 & $\mathrm{I}_{2}+\mathrm{e}^{-} \rightarrow \mathrm{I}_{2}^{\cdot-}$ & $5.1 \times 10^{10}$ \\
\hline 127 & $\mathrm{I}^{-}+\mathrm{O}^{\bullet-}+\mathrm{H}_{2} \mathrm{O} \rightarrow \mathrm{HOI}^{\bullet-}+\mathrm{OH}^{-}$ & $2.9 \times 10^{9} M^{-2} s^{-1}$ \\
\hline
\end{tabular}

Table S6. Iron Radiolysis Reactions

Reaction Reaction

Number
Rate Constant

Reference 


$\begin{array}{lccc}\mathbf{1 2 8} & \mathrm{Fe}^{2+}+\mathrm{H}_{2} \mathrm{O}_{2} \rightarrow \mathrm{Fe}^{3+}+\cdot \mathrm{OH}+\mathrm{OH}^{-} & 60 & \left({ }^{21}\right) \\ \mathbf{1 2 9} & \mathrm{Fe}^{3+}+\mathrm{e}_{\mathrm{aq}}^{-} \rightarrow \mathrm{Fe}^{2+} & 6 \times 10^{10} & \left({ }^{22}\right) \\ \mathbf{1 3 0} & \mathrm{H}^{-}+\mathrm{Fe}^{3+} \rightarrow \mathrm{H}^{+}+\mathrm{Fe}^{2+} & 7 \times 10^{5} & \left({ }^{23}\right) \\ \mathbf{1 3 1} & \mathrm{HO}_{2}{ }^{+}+\mathrm{Fe}^{3+} \rightarrow \mathrm{H}^{+}+\mathrm{O}_{2}+\mathrm{Fe}^{2+} & 2.1 \times 10^{5} & \left({ }^{24}\right) \\ \mathbf{1 3 2} & \mathrm{Fe}^{2+}+{ }^{-} \mathrm{OH} \rightarrow \mathrm{Fe}^{3+}+\mathrm{OH}^{-} & 3.1 \times 10^{8} & \left({ }^{25}\right)\end{array}$




\section{References}

1. Hauwiller, M. R. et al. Gold Nanocrystal Etching as a Means of Probing the Dynamic Chemical Environment in Graphene Liquid Cell Electron Microscopy. J. Am. Chem. Soc. 141, 4428-4437 (2019).

2. Wardman, P. Reduction Potentials of One-Electron Couples Involving Free Radicals in Aqueous Solution. J. Phys. Chem. Ref. Data 18, 1637-1755 (1989).

3. Hayon, E., Treinin, A. \& Wilf, J. Electronic spectra, photochemistry, and autoxidation mechanism of the sulfite-bisulfite-pyrosulfite systems. $\mathrm{SO}_{2}^{-}, \mathrm{SO}_{3}^{-}, \mathrm{SO}_{4}^{-}$, and $\mathrm{SO}_{5}^{-}$ radicals. J. Am. Chem. Soc. 94, 47-57 (1972).

4. Sastre, S., Casasnovas, R., Muñoz, F. \& Frau, J. Isodesmic reaction for accurate theoretical pKa calculations of amino acids and peptides. Phys. Chem. Chem. Phys. 18, 11202-11212 (2016).

5. Marenich, A. V., Cramer, C. J. \& Truhlar, D. G. Universal solvation model based on solute electron density and on a continuum model of the solvent defined by the bulk dielectric constant and atomic surface tensions. J. Phys. Chem. B 113, 6378-6396 (2009).

6. Ho, J. Are thermodynamic cycles necessary for continuum solvent calculation of pKas and reduction potentials? Phys. Chem. Chem. Phys. 17, 2859-2868 (2015).

7. Schneider, N. M. et al. Electron-Water Interactions and Implications for Liquid Cell Electron Microscopy. J. Phys. Chem. C 118, 22373-22382 (2014).

8. El Omar, A. K., Schmidhammer, U., Rousseau, B., LaVerne, J. \& Mostafavi, M. Competition Reactions of $\mathrm{H}_{2} \mathrm{O}^{-+}$Radical in Concentrated $\mathrm{Cl}^{-}$Aqueous Solutions: Picosecond Pulse Radiolysis Study. J. Phys. Chem. A 116, 11509-11518 (2012).

9. Bjergbakke, E., Navaratnam, S., Parsons, B. J. \& Swallow, A. J. Reaction between 
hydroperoxo radicals and chlorine in aqueous solution. J. Am. Chem. Soc. 103, 5926-5928 (1981).

10. Zehavi, D. \& Rabani, J. The oxidation of aqueous bromide ions by hydroxyl radicals. A pulse radiolytic investigation. J. Phys. Chem. 76, 312-319 (1972).

11. Merényi, G. \& Lind, J. Reaction mechanism of hydrogen abstraction by the bromine atom in water. J. Am. Chem. Soc. 116, 7872-7876 (1994).

12. Wolff, T. Laser Flash Photolysis of $\mathrm{HClO}, \mathrm{ClO}^{-}, \mathrm{HBrO}$, and $\mathrm{BrO}^{-}$in Aqueous Solution. Reactions of C1- and Br-Atoms. 245, 243-245 (1985).

13. Hata, K. et al. Hydrogen Peroxide Production by Gamma Radiolysis of Sodium Chloride Solutions Containing a Small Amount of Bromide Ion. Nucl. Technol. 193, 434-443 (2016).

14. Ershov, B. G., Kelm, M., Janata, E., Gordeev, A. V. \& Bohnert, E. Radiation-chemical effects in the near-field of a final disposal site: Role of bromine on the radiolytic processes in NaCl-solutions. Radiochim. Acta 90, 617-622 (2002).

15. Matthew, B. M. \& Anastasio, C. A chemical probe technique for the determination of reactive halogen species in aqueous solution: Part 1 - Bromide solutions. Atmos. Chem. Phys. 6, 2423-2437 (2006).

16. Sutton, H. C. \& Downes, M. T. Reactions of the $\mathrm{HO}_{2}$ radical in aqueous solution with bromine and related compounds. J. Chem. Soc. Faraday Trans. 1 Phys. Chem. Condens. Phases 68, 1498 (1972).

17. Sutton, H. C., Adams, G. E., Boag, J. W. \& Michael, B. D. Radical Yields and kinetics in the pulse radiolysis of potassium bromide solutions. in Pulse Radiolysis 61-81 (1965).

18. Buxton, G. V. \& Mulazzani, Q. G. On the hydrolysis of iodine in alkaline solution: A 
radiation chemical study. Radiat. Phys. Chem. 76, 932-940 (2007).

19. Ishigure, K., Shiraishi, H. \& Okuda, H. Radiation chemistry of aqueous iodine systems under nuclear reactor accident conditions. Int. J. Radiat. Appl. Instrumentation. Part C. Radiat. Phys. Chem. 32, 593-597 (1988).

20. Schwarz, H. A. \& Bielski, B. H. J. Reactions of $\mathrm{HO}_{2}$ and $\mathrm{O}_{2}^{-}$with iodine and bromine and the $\mathrm{I}_{2}^{-}$and I atom reduction potentials. J. Phys. Chem. 90, 1445-1448 (1986).

21. Malato, S., Fernández-Ibáñez, P., Maldonado, M. I., Blanco, J. \& Gernjak, W. Decontamination and disinfection of water by solar photocatalysis: Recent overview and trends. Catalysis Today 147, 1-59 (2009).

22. Jonah, C. D., Miller, J. R. \& Matheson, M. S. The reaction of the precursor of the hydrated electron with electron scavengers. J. Phys. Chem. 81, 1618-1622 (1977).

23. Dainton, F. S., Holt, B. J., Philipson, N. A. \& Pilling, M. J. Reactions of hydrogen atoms in $6 \mathrm{~mol} \mathrm{dm}^{-3}$ sulphuric acid. Part 2.- The transition from activation to diffusion control. J. Chem. Soc. Faraday Trans. 1 Phys. Chem. Condens. Phases 72, 257 (1976).

24. Sehested, K., Bjergbakke, E., Rasmussen, O. L. \& Fricke, H. Reactions of $\mathrm{H}_{2} \mathrm{O}_{3}$ in the Pulse-Irradiated Fe(II)-O 2 System. J. Chem. Phys. 51, 3159-3166 (1969).

25. Stuglik, Z. \& PawełZagórski, Z. Pulse radiolysis of neutral iron(II) solutions: oxidation of ferrous ions by OH radicals. Radiat. Phys. Chem. 17, 229-233 (1981). 